\section{Igor Eterović}

Medicinski fakultet Sveučilišta u Rijeci

Katedra za društvene i humanističke

znanosti u medicini

Braće Branchetta 20, HR-51000 Rijeka

igor.eterovic@medri.uniri.hr

\section{Ivana Eterović}

Filozofski fakultet Sveučilišta u Zagrebu

Odsjek za kroatistiku

Ivana Lučića 3, HR-10000 Zagreb

isankovi@ffzg.hr

\title{
Devet lovranskih oporuka iz druge polovice 18. stoljeća: povijesna $i$ jezična analiza
}

Prethodno priopćenje | Preliminary communication UDK 347.67:930.85>(497.5 Lovran)《17《

Primljeno | Received: 26. X. 2012

\section{Izvadak}

U fondu Javni bilježnici Rijeke i okolice pohranjenu u Državnome arhivu u Rijeci nalazi se i vrijedna zbirka lovranskih oporuka iz 18. stoljeća. U radu se analizira devet oporuka iz toga fonda koje su u potpunosti pisane hrvatskim jezikom. Sve oporuke kao notar potpisuje Anton Tomičić, osim najmlađe, na kojoj je potpisan Bartol Negovetić. Ovdje se prikazuje njihova latinička grafija te analiziraju najvažnije jezične značajke na fonološkoj i morfološkoj razini. Budući da su oporuke ne samo prvoklasno vrelo za istraživanje povijesti jezika već i nezamjenjiv izvor podataka o široj povijesnoj svakodnevici Lovrana, u radu se upozorava i na različite dimenzije svakodnevice Lovrana 18. stoljeća koje se iz oporuka kao povijesnih izvora mogu iščitati (npr. pravni uzusi, položaj žene, pobožnost).

\section{Sintesi}

Il fondo „Notai pubblici di Fiume ed i suoi dintorni" (Javni bilježnici Rijeke i okolice), che si conserva nell'Archivio di Stato di Fiume (Državni arhiv u Rijeci), contiene una collezione preziosa dei testamenti lauranesi del $18^{\circ}$ secolo. In quest'articolo vengono analizzati i nove testamenti i quali sono completamente scritti in lingua croata. Tutti questi testamenti sono firmati dal notaio Anton Tomičić, tranne il più recente, che è firmato da Bartol Negovetić. Qui si presenta la loro scrittura latina e si analizzano le caratteristiche più importanti sul livello fonologico e morfologico. Siccome i testamenti non sono solo una fonte straordinaria per la ricerca della storia della lingua ma anche una fonte indispensabile per studiare i fatti sulla vita di tutti i giorni di Laurana, in quest'articolo vengono segnalate le diverse dimensioni della vita quotidiana di Laurana nel $18^{\circ}$ secolo le quali si possono leggere dai testamenti come fonti storiche (ad esempio costumi legislativi, lo stato della donna, religiosità). 
Ključne riječi: oporuke, Lovran, kancelarija, Anton Tomičić, Bartol Negovetić, hrvatski jezik, latinica, 18. stoljeće

Parole chiavi: testamenti, Laurana, cancelleria, Anton Tomičić, Bartol Negovetić, lingua croata, scrittura latina, $18^{\circ}$ secolo

U fondu Javni bilježnici Rijeke i okolice (signatura: HR-DAR-41) pohranjenu u Državnome arhivu u Rijeci čuva se i vrijedna zbirka lovranskih ${ }^{1}$

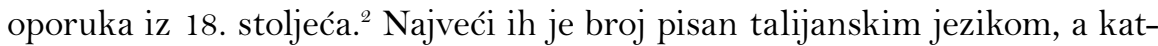
kad sadrže i rijetke zapise na hrvatskom. ${ }^{3} \mathrm{U}$ potpunosti je hrvatskim jezikom napisano devet oporuka, od kojih osam potpisuje notar Anton Tomičić (jednu iz 1773., šest iz 1774. i jednu iz 1775.), a najmlađu, onu iz 1777., Bartol Negovetić. ${ }^{4}$ Faksimil, prijepis i transkripcija tih oporuka već su objavljeni, ${ }^{5}$ no zbog ograničena su prostora opisane samo njihove vanjske karakteristike. ${ }^{6}$ U ovome se radu koncentriramo isključivo na analizu njihovih unutarnjih karakteristika: strukturu, sadržaj i jezik, pričem je naš osnovni cilj iskoristiti dragocjenu građu s povijesnoga i filološkoga aspekta. ${ }^{7}$ Dio je to šire zacrtana istraživanja koje će obuhvatiti i druge isprave iz fonda Javni bilježnici Rijeke i okolice, prije svega s područja Lovrana i Lovranštine, i

1 Atribut lovranski označuje da je riječ o oporukama u čijoj se zemljopisnoj dataciji nalazi nedvosmisleno određenje da su sastavljene u Lovranu, odnosno na području koje mu pripada.

2 Spomenuti fond sadrži i isprave s drugih područja Rijeke i okolice, na što upućuju njihove zemljopisne datacije (npr. Veprinac, Kastav). Nije inventariziran u potpunosti, a obuhvaća pet svežanja gradiva. V. Boris Zakošek, „Pregled arhivalija Lovranštine do 1945. u Državnom arhivu u Rijeci“, Zbornik Lovranšćine, 1, 2010., 24.

3 Npr.: „Testa, dice, et Lascia alla detta Figliola Margharita li cinque Costagnari giouani, et un grande Sopra Calich in Banouaz Sgora perili poli Cernizze [istaknuli autori]“ (Državni arhiv u Rijeci, HR-DAR-41, Javni bilježnici Rijeke i okolice, sv. 24, dok. 00001) ili „Item alla Sua Nipote Cattarina Orbanich li Maronari pod Cattizun, na ki i na Bachinovacz da ima dat due S. Mafse do Lett duaifset, za gniu Testadurizu, i gne Matter pokojnu [istaknuli autori] “ (isto, dok. 00014).

4 Hrvatskim je jezikom pisana i jedna dispozicija (središnji dio oporuke u kojoj se nalaze ostavinske odredbe) iz 1798., a najvjerojatnije je trebala poslužiti kao nacrt za naknadno sastavljanje službene oporuke (HR-DAR-41, Javni bilježnici Rijeke i okolice, sv. 25, dok. 00177). Budući da nije riječ o službeno ovjerenoj oporuci te da potječe iz mlađega razdoblja, ta dispozicija nije ušla u korpus ove analize. Valja napomenuti i da je dijelom ovoga fonda, vjerojatno pogreškom, još jedna isprava pisana hrvatskim jezikom: predbračni ugovor sastavljen u Mošćenicama 1801. (HR-DAR-41, Javni bilježnici Rijeke i okolice, sv. 25, dok. 00332).

5 Ivana Eterović - Igor Eterović, „Devet oporuka iz lovranske kancelarije na hrvatskome jeziku iz 18. stoljeća pohranjenih u Državnome arhivu u Rijeci“ (dalje: „Devet oporuka iz lovranske kancelarije“), Zbornik Lovranšcine, 2, 2012., 35-84.

6 U diplomatičkome se smislu oporuke, kao i druge isprave (povelje, listine), mogu opisati na temelju vanjskih i unutarnjih karakteristika. Više o diplomatici i definiciji isprave v. u: Jakov Stipišić, Pomoćne povijesne znanosti u teoriji $i$ praksi, Zagreb 1985., 141-143, a o unutarnjim i vanjskim karakteristikama isprave $\mathrm{u}$ : isto, $150-157$.

7 Naravno, taj će potencijal biti iskorišten u onoj mjeri u kojoj nam to dopušta ograničenost prostora. Nadamo se da će ova analiza poslužiti u daljnjim istraživanjima oporuka i novim perspektivama u njihovu čitanju. 
to ne samo one na hrvatskome jeziku. ${ }^{8}$ Budući da je prošlost Lovrana još uvijek slabo istražena i nedovoljno poznata, isprave iz spomenutoga fonda dragocjen su izvor podataka o povijesnoj svakodnevici Lovrana (i okolice) 18. stoljeća.

\section{Povijesni kontekst nastanka oporuka i njihova specifičnost kao izvora}

Svih je devet oporuka nastalo u bilježničkoj (notarskoj ${ }^{9}$ ) kancelariji Lovrana. Iako bi za austrijski dio Istre, kojemu je Lovran pripadao u to vrijeme, ${ }^{10}$ možda bilo primjerenije govoriti o kancelarijama (Kanzlei, cancelaria, cancelleria itd.), a tek za onaj mletački o notarijatima (notariato, officio notarile itd.), funkcionalno gledano, i kancelarije (općinski uredi) kao sjedišta lokalne vlasti, odnosno njihovi službenici (kancelari), obavljale su funkcije javnoga bilježništva, ${ }^{11}$ napose kad je postojala potreba za izradom privatno-poslovnih isprava (oporuka, kupoprodajnih ugovora itd.). ${ }^{12}$ Iako je u pravnome smislu područje na kojemu je i Lovran ${ }^{13}$ bilo „u sferi utjecaja njemačkih feudalaca i kasnije Habsburgovaca“, ${ }^{14}$ dodatni je specifikum ovoga područja postojanje - usprkos austrijskoj upravi nad njim - snažna i nezaobilazna

8 Osobito se dragocjeni podaci kriju u oporukama pisanim talijanskim jezikom, koje sadrže bogatu onomastičku građu.

9 U katalogu izložbe dokumenata iz pravne povijesti područja u koje je uključen i Lovran D. Klen piše općenito o notarijatu: „Notarske isprave, instrumente pišu notari. Notar je osoba kojoj je posebnim ovlaštenjem priznato pravo pisanja javnih isprava. (...) Nalazimo, međutim, i notara i pisara koji se nazivaju naprosto gradskim notarima. Strogost ocjenjivanja kriterija za podjeljivanje notarskog ovlaštenja zacijelo nije uvijek bila jednaka." Statuti, urbari, notari Istre, Rijeke, Hrvatskog primorja i otoka, katalog izložbe, odg. ur. Danilo Klen, Rijeka 1968., 21.

10 Lovran je u to vrijeme (do propasti Venecije 1797.) bio dijelom austrijskoga dijela Istre, poznatoga pod nazivom Pazinska knežija (Pazinski feud), i to dijelom Knežije u užem smislu, tj. pod izravnom upravom pazinskoga kneza. Usp. Slaven Bertoša, „Pazinska knežija“, Istarska enciklopedija, ur. Miroslav Bertoša i Robert Matijašić, Zagreb 2005., 578.

11 U vrijeme mletačke i prve austrijske uprave (1200. - 1806.) bilježnici su „djelovali unutar sustava lokalne uprave, pri istarskim općinama i gradovima“. Iva Grdinić, „Sumarno-analitički inventar fonda Bilježnički arhiv u Puli (1645/1954)“" Vjesnik istarskog arhiva, 14-16, 2007--2009. (2010.), 26.

12 Vrlo je važan osvrt S. Antoljaka, koji u vezi s notarskom službom u Hrvatskome primorju u razdoblju do pada Venecije (1797.) ističe kako se ovdje notar često „naziva carski, općinski notar i sl. (...) Nadalje, ovi isti notari često su još i kancelari komuna, gdje su radili. Kao i drugi tako i oni vode svoje notarske knjige kvaderne ili naprosto knjige." Stjepan Antoljak, Pomoćne istorijske nauke, Kraljevo 1971., 78. S tim u vezi dodatno treba istaknuti da se vrlo često i u mletačkome dijelu Istre upotrebljavao naziv kancelarija (cancelaria), ali u smislu notarskoga ureda u kojemu su se čuvali javni spisi, bilježničke knjige i oporuke (usp. Josip Kolanović, „Arhivi“, Istarska enciklopedija, 31), pa se naziv kancelarija i kancelar (kanciler) zasigurno upotrebljavao u širem značenju obuhvaćajući i notarske usluge koje su se u njih pružale. Tomu u prilog možemo dodati činjenicu da se vrlo rano (već od 13. st.) na istočnoj obali Jadrana termini notar (notarius) i kancelar (cancellarius) rabe praktički sinonimno (usp. Milan pl. Šufflay, Dalmatinsko-hrvatska srednjovjekovna listina: povijest hrvatskoga notarijata od XI. do XV. stoljeća [dalje: Dalmatinsko-hrvatska srednjovjekovna listina], ur. i prev. Darko Sagrak, Zagreb 2000., 37).

13 Misli se na liburnijski dio Knežije. Za određenje područja Liburnije v. Robert Matijašić, „Liburnija“, Istarska enciklopedija, 441.

14 Lujo Margetić, Hrvatsko srednjorjekorno obiteljsko i nasljedno pravo (dalje: Hrv. srednjovj. obiteljsko i nasljedno pravo), Zagreb 1996., 133. 
mletačkoga utjecaja ne samo na razini jezika i terminologije ${ }^{15}$ već i na razini svakodnevne prakse i funkcioniranja. ${ }^{16} \mathrm{U}$ skladu s tim Antona Tomičića i Bartola Negovetića nazivamo javnim bilježnicima (notarima), stavljajući u prvi plan njihovu pravnu funkciju s obzirom na narav sastavljenih isprava.

Za svaku komunu notarijat ima posebnu važnost. Služba notara ubrajala se među ugledne općinske službe jer su notari „imali značajnu ulogu u životu i općenito funkcioniranju komune te su stoga sve isprave koje su sastavljali uživale javnu vjeru. ${ }^{\text {“17 }}$ Općenito vrijedi da je ,javni notarijat u mediteranskim gradovima bio ekstremno važan i da je ostavio snažan utisak na način kako su se oporuke sastavljale i izvršavale. ${ }^{\text {18 }}$

Testament ili oporuka vrsta je privatne isprave ${ }^{19}$ te kao takva ima svoga autora (auctor) - oporučitelj, destinatara (destinatarius) - nasljednici, i pisara (rogatarius, scriptor) - javni bilježnik..$^{20}$ „Testament, kao i svaki drugi pravni akt, ima svoje odlike i postulate. Prije svega on mora biti: jednostrana izjava oporučiteljeve volje, osobni oporučiteljev akt, strogo formalni akt i promjenljiv u dijelu ili cjelini, uključujući i opoziv, što može učiniti samo testator, uz uvjet postojanja oporučiteljeve moći rasuđivanja i osiguranja njegove slobodne volje. Osim spomenutoga u testamentu se precizira i vrijeme i okolnosti pravljenja, a bitno je i njegovo proglašenje glede punovaljanosti. ${ }^{\text {(21 }}$

15 Jedan je od najizrazitijih pokazatelja upravo jezik, a zanimljivo je da su sve ostale oporuke iz fonda koji je ovdje u fokusu pisane talijanskim jezikom, s jasnim utjecajem mletačke notarske prakse, prije svega u terminologiji. Ovdje je dovoljno izdvojiti nekoliko primjera iz Kvaderne kapitula lovranskoga u kojima se zapisivač, svećenik lovranskoga kaptola, istovremeno naziva „nodar i kancaler i kanonik kapitula lovranskoga“ (Damir Viškanić, Quaderna capituli Lovranensis / Kvaderna kapitula lovranskoga [dalje: Quaderna capituli Lovranensis], Lovran - Rijeka 2002., 61), ,nodar i kancaler grada Lovrana“ (isto, 81, 91), odnosno „nodar i kancalir grada Lovrana“ (isto, 113). Treba imati na umu da ne postoji neka veća razlika između mletačke i naše notarske prakse jer su se tada i jedni i drugi školovali u talijanskim sveučilišnim centrima, prije svega Bolonji i Padovi kao žarištima notarskoga školovanja, a i sam početak notarske prakse na istočnojadranskoj obali započeo je upravo pod utjecajem notarskih škola iz Italije. Usp. Branka Grbavac, „Notarska služba i komunalno zakonodavstvo - notari u statutima Raba, Zadra, Šibenika, Splita i Trogira“ (dalje: „Notarska služba i komunalno zakonodavstvo“), 2. Istarski povijesni biennale. Sacerdotes, iudices, notarii...: posrednici medu društvenim skupinama, Poreč 2007., 59; Branka Grbavac, Notarijat na istočnojadranskoj obali od druge polovine 12. do kraja 14. stoljeća (dalje: Notarijat na istočnojadranskoj oball), doktorska disertacija, neobjavljeno, Zagreb 2010., 66, 71, 78; Zoran Ladić, Last Will: Passport to Heaven. Urban Last Wills from Late Medieval Dalmatia with Special Attention to the Legacies Pro Remedio Animae and Ad Pias Causas (dalje: Last Will), Zagreb 2012., 75.

16 Najjasniji je dokaz za tu tvrdnju uporaba mletačkoga novca i na području austrijske Istre (usp. Viškanić, Quaderna capituli Lovranensis, 320). Ta je činjenica osobito važna u iščitavanju novčanih vrijednosti u oporukama.

17 Grbavac, „Notarska služba i komunalno zakonodavstvo“, 60.

18 Ladić, Last Will, 73.

19 Privatnom se ispravom općenito smatra ona „koju izdaju ovlaštene osobe u uredima ili kancelarijama u obliku koji se redovno upotrebljava u poslovnim ugovorima." Stipišić, Pomoćne povijesne znanosti u teoriji i praksi, 159.

20 Isto, 158.

21 Marijan Sivrić, Oporuke Kancelarije stonskog kneza od sredine 15. stoljé́a do 1808. godine (dalje: Oporuke Kancelarije stonskog kneza), Dubrovnik 2002., 47. 
Treba još istaknuti da su testamentarne odredbe troznačne, a svaka od njih ima svoj smisao: 1. materijalnopravne odredbe o nasljedivanju (određivanje univerzalnoga nasljednika, određivanje i naznaka oporučne kvote - novca, nabrajanje pokretne i nepokretne imovine koja se oporučuje te određivanje naloga ili zapovijedi o izvršenju); 2. formalnopravne odredbe (određivanje izvršitelja oporuke, određivanje osobe ili više njih koja će se brinuti o izvršenju oporučiteljeve volje) i 3. nenasljedne pravne odredbe (određivanje staratelja malodobnoj djeci, priznavanje duga prema drugima ili opraštanje duga dužniku, način i mjesto izvršenja oporuke). Testamentarni svjedoci (testimonii) također su važan čimbenik u oporukama, pri čemu se mora udovoljiti zahtjevima u pogledu punoljetnosti i pravne sposobnosti svjedoka. ${ }^{22}$

$\mathrm{U}$ podjeli notarskih isprava po vrstama one isprave koje se bave provođenjem posljednje volje zauzimaju posebno mjesto, pa tako uz privatne isprave u užem smislu (instrumente), notarske zapise (note) i popise imovine (inventare) razlikujemo kao posebne vrste oporuke (testamente) i notarske zapisnike (brevijarije). ${ }^{23}$ Oporuke, kao dokumenti koji se odnose na provođenje posljednje volje, dalje dijelimo na testamente ili oporuke u užem smislu, kodicile (nadopune i izmjene oporuke) te darovanja u slučaju smrti. Brevijariji su se prvenstveno odnosili na zapisnike javnih dražbi i oporuka, pri čemu se kasnije, pogotovo u novom vijeku, uglavnom pri govoru o brevijarima misli na brevijarije oporuka. ${ }^{24}$

Kao povijesni izvor oporuke su posebno vrijedne jer su, uz darovnice, „najstariji definirani oblici privatno-pravne isprave, koji se susreću već i prije pojave institucionaliziranog oblika notarijata“25 sa svojim jasnim, preciznim i dosljednim formulama i uzusima sastavljanja koji se nisu prečesto mijenjali pa stoga omogućavaju adekvatnu komparativnu analizu notarskih praksi kako u različitim vremenskim razdobljima, tako i u različitim komunalnim središtima. ${ }^{26}$

Iako se oporuke svrstavaju u privatne isprave, one također imaju javnu vjeru (fidem publicam), a razlikuju se od javnih isprava uglavnom oblikom. Kao akt javne vjere notarski se akt, odnosno notarska isprava naziva javni

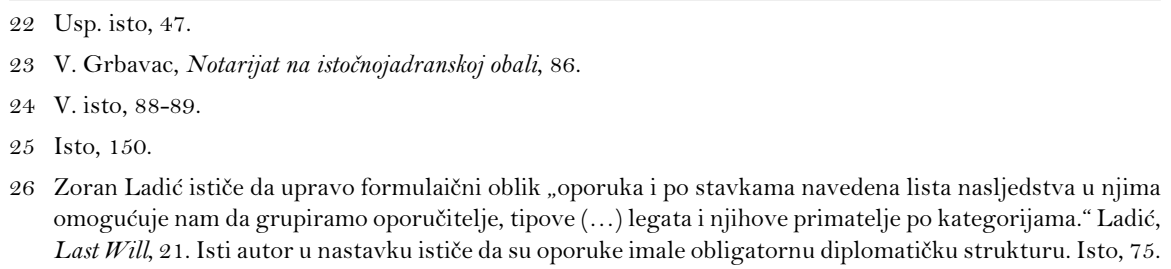

26 Zoran Ladić ističe da upravo formulaični oblik „oporuka i po stavkama navedena lista nasljedstva u njima omogućuje nam da grupiramo oporučitelje, tipove (...) legata i njihove primatelje po kategorijama.“Ladić, Last Will, 21. Isti autor u nastavku ističe da su oporuke imale obligatornu diplomatičku strukturu. Isto, 75. 
instrument (instrumentum publicum).${ }^{27}$ Općenito je vrijedilo da „častan bilježnik nije smio, pod velikom kaznom, strankama uskratiti svoju službu, tj. uslugu (officium), kako je on na to bio obvezan i pod zakletvom. Isto mu tako malo tho smije zabraniti izradu instrumenta. ${ }^{\text {(28 }}$ Treba istaknuti da $\mathrm{u}$ Lovranu, osim notarske kancelarije, mjesto javne vjere u 18. stoljeću predstavlja i lokalni kaptol, ${ }^{29}$ što govori u prilog tezi da je Lovran u to vrijeme predstavljao snažno administrativno središte, koje je posjedovalo i javni (civilni) notarijat i kaptolsku kancelariju.

\section{Grafija30}

Svih je devet oporuka pisano hrvatskom nenormiranom dopreporodnom latinicom. ${ }^{31}$ Najveće razlike između Tomičićevih oporuka i Negovetićeve zamjetne su upravo na grafijskoj razini. Iako obojica notara oblikuju grafiju po talijanskome ${ }^{32}$ uzoru, njihova su rješenja različita.

27 Usp. Stipišić, Pomoćne povijesne znanosti u teorïi i praksi, 159, 162 i Grbavac, „, Notarska služba i komunalno zakonodavstvo“, 60. Budući da je Lovran bio okružen aktivnom notarskom djelatnošću, vjerojatno se javni notarijat i ovdje razvio dosta rano. Naime s jedne strane „od sredine 14. stoljeća vlada objektivni instrument od kvarnerskih otoka i Senja do Dubrovnika i Lastova“ (Šufflay, Dalmatinsko-hrvatska srednjorjekovna listina, 84), dok s druge strane na istočnoj obali Istre, u Labinu, postoji snažna notarska aktivnost u 16. stoljeću (usp. Zoran Ladić - Elvis Orbanić [prir.], Knjiga labinskog bilježnika Bartolomeja Gervazija [1525-1550], Spisi istarskih bilježnika I, Spisi labinskih bilježnika, sv. 1, Posebna izdanja Državnog arhiva u Pazinu, svezak 17, Pazin 2008.).

28 Šufflay, Dalmatinsko-hrvatska srednjovjekovna listina, 97. Iako je M. Šufflay ovo isticao prvenstveno za srednjovjekovni notarijat u primorskim gradovima, možemo to uzeti kao opće načelo koje je vrijedilo daleko šire i još mnogo poslije, sve do napoleonskih reformi (usp. isto, 21).

29 O tome nam svjedoče zapisi u Kvaderni kapitula lovranskoga, u kojoj se nalazi po jedna sačuvana oporuka iz 16., 17. i 18. stoljeća. Usp. Viškanić, Quaderna capituli Lovranensis, 303-309.

30 Primjeri se citiraju po modelu Antich ${ }_{1 . q}$, gdje brojka ispred dvotočja precizira o kojoj je oporuci riječ, a brojka iza dvotočja redak u kojemu se primjer nalazi. Jednostavnosti radi svakoj je naime oporuci pridružena brojka, i to po kronološkome načelu: (1) 5. prosinca 1773., (2) 23. veljače 1774., (3) 24. veljače 1774., (4) 11. travnja 1774., (5) 4. rujna 1774., (6) 25. rujna 1774., (7) 14. studenoga 1774., (8) 24. ožujka 1775., (9) 25. kolovoza 1777. Na svim su mjestima primjeri transkribirani osim u poglavlju o grafiji, gdje je zadržano i pisanje velikoga početnoga slova iz predloška. Prijepis i transkripcija izvorâ objavljeni su u: Iv. Eterović - Ig. Eterović, „Devet oporuka iz lovranske kancelarije“, 60-83. Primjeri koji se ponavljaju načelno se ne donose, osim kada se želi istaknuti da je što jednako ili različito u obojice notara.

31 Od samih početaka bilježenja hrvatskoga jezika latiničkim pismom sve do preporoda osnovni je problem bio način zapisivanja palatala. Grafijska se praksa razlikovala od razdoblja do razdoblja, od regije do regije, od pisca do pisca, a katkad je nedosljedna čak i u djelima istoga pisca. Na temelju latiničkih tekstova 95 pisaca čija su mu djela bila građom za raspravu o povijesti bilježenja hrvatskoga jezika latinicom Tomo Maretić navodi da su se primjerice fonemi /č/ i /̌̌/ mogli pisati na 18, a /ć/ i /š/ na 22 različita načina (Tomo Maretić, Istorija hrvatskoga pravopisa latinskijem slovima, Zagreb 1889., 348-367). Višeznačnost grafema, koji najčešće imaju nekoliko glasovnih vrijednosti, i česta nedosljednost u pisanju otežavaju transkripciju, osobito u određivanju bilježi li se kojim grafemskim slijedom fonem ili fonemski slijed te pri utvrđivanju fonoloških alternacija (v. Dragica Malić, „Nedoumice u transkripciji stare hrvatske latinice“, Suvremena lingvistika, 43/44, 1997., 153-154). „Najčešći su nizovi fonema što se pišu istim grafemima $c-\check{c}$, $h-k, i-j-g, l-l, n-\dot{n}, s-z-\check{s}-\check{z}, u-v$, ali ima i drugih, manje običnih preklapanja.“ (isto, 155). Takvo se stanje može zapaziti i u ovim oporukama.

32 U kontinentalnoj se Hrvatskoj latinica uređivala po uzoru na mađarski, a u južnoj (i obalnoj) Hrvatskoj po uzoru na latinski i talijanski jezik, no ni unutar tih dviju skupina rješenja nisu bila ujednačena. V. Milan Moguš - Josip Vončina, „Latinica u Hrvata“, Radovi Zavoda za slavensku filologiju, 11, 1969., 62-63; Maretić, Istorija hrvatskoga pravopisa latinskijem slovima. 


\section{1. Tomičićeva grafija}

Fonem /ć/ bilježi se grafemom $c h$ na kraju riječi te ispred vokala $i$, e: Antich

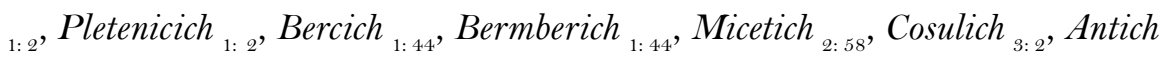
3: 2 , Petricich ${ }_{5: 2}$, Palmich $_{5: 2}$; buduchi $_{1: 2}$, imagiuchi ${ }_{1: 5}$, peschinu ${ }_{1: 30}$, Hchere ${ }_{1:}$ ${ }_{32}$, hoche $_{2: 9}$, ordinugiuchi $_{2: 13}$, profsechi ${ }_{2: 15}$, Baschinu ${ }_{2: 28}$, Xivuchi ${ }_{2: 35}$, Hcheram 2: 39 , priporucugiuchi ${ }_{\text {2: } 38}$, puscheni ${ }_{\text {2: } 47}$, Marlincichia ${ }_{2: 52}$, hoche ${ }_{\text {2: } 54}$, pristogieche 4:13, Prischichem $_{4: 24}$, techuchega ${ }_{6: 5-6}$, pohischinun ${ }_{7: 30-31}$, Suegamoguchi ${ }_{8: 10}$. U ostalim se položajima bilježi grafemom chi: puschia ${ }_{1: 6}$, , kuchiun $_{1: 7}$, Mattichiu ${ }_{1: 37-38}$, Michulicichia $_{2: 3}$, kuchia $_{2: 12}$, plachiat $_{2: 46}$, Marlincichia $_{2: 52}$, Bachichiu $_{4: 16}$, Srechia $_{5: 15}$, Antichiu $_{5: 18}$.

Fonem /č/ bilježi se grafemom $c$ ispred vokala $i$ i $e$ : Pletenicich ${ }_{1: 2}$, Cetiri ${ }_{1: 5}$, ucinit $_{1: 8}$, cetertomu ${ }_{1: 22}$, receneh ${ }_{1: 23}$, ocitoval ${ }_{1: 32}$, cinit ${ }_{1: 40}$, Michulicichia $_{2: 3}$,

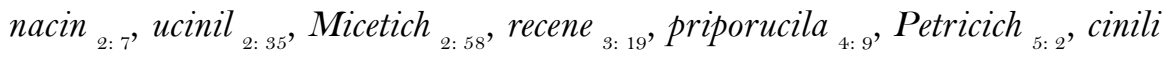
${ }_{5: 5}$, Martincichem $_{6: 18}$. Isti se grafem javlja često i u ostalim položajima: $c a_{2:}$ ${ }_{28}$, priporucugiuchi $_{2: 38}, z a c_{7: 7}$, Cresgne $_{7: 14}$. Na početku riječi često se za ovaj fonem rabi grafem $c$ s podrednim znakom (c), rijetko i u sredini riječi ispred $i$, e: $c u t_{1: 3}, c a_{1: 10}$, oçitugie ${ }_{2: 48}, c a_{6: 14}, c a_{7: 25}$. Posve su rijetki primjeri bilježenja nekim drugim grafemom, npr. z: Suedozanstvo $2: 58^{.}$

Fonem /c/ najčešće se bilježi grafemom $c z:$ poloviczu $_{1: 18}$, ovacz 1:29,

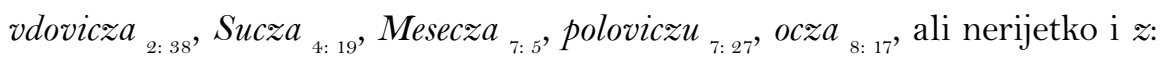
Gospodarizu $_{1: 26}$, Sudaz $_{4: 7}$, intenzion ${ }_{6: 11}$, Gospodarize $_{8: 5}$.

Fonem /ž/ načelno se bilježi grafemom $x$ : duxnofte ${ }_{1: 3-4}$, Xene ${ }_{1: 6}$, Xenu ${ }_{1: 25}$, Boxgioj $_{2: 4}$, Xivotu $_{2: 5}$, Boxastvenemi ${ }_{2: 11-12}$, Xivel $_{2: 21}$, Xivuchi ${ }_{2: 35}$, Duxan ${ }_{2: 48}$, uxivangie $_{5: 10}$, Xitka ${ }_{7: 33}$. Rjede se za ovaj fonem rabe i drugi grafemi: $s$

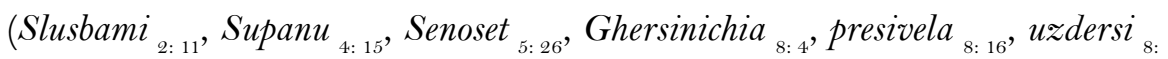
$\left.{ }_{4}\right), z\left(\right.$ zivuchi $\left.{ }_{3: 12-13}\right)$.

Fonem /ń/ bilježi se grafemom gn (gnighovu ${ }_{1: 3}$, zadgnu $_{1: 3-4}$, gnighovoj ${ }_{1: 5}$ Coftagna $_{1: 14}$, Coftagneva ${ }_{1: 15}$, gneghovi ${ }_{1: 21}$, gnih $_{1: 22}$, gne $_{1: 26}$, gnemu $_{1: 31}$, gnoj $_{1: 32}$, gneghov ${ }_{1: 39}$, danafsgni ${ }_{2: 6}$, gneghova ${ }_{2: 12}$, gnighovu ${ }_{2: 15-16}$, gneghovega

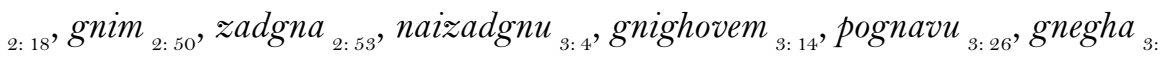

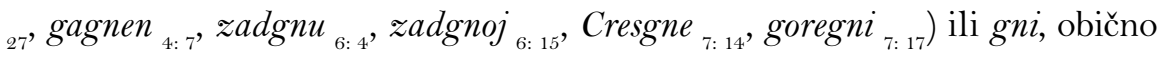

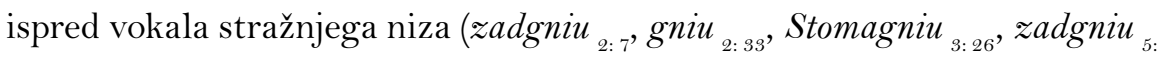
s). Iznimno u grafiji za ovaj fonem dolazi $n g$, samo na kraju riječi: Costang ${ }_{1:}$ ${ }_{30}$, Coftang $_{2: 31}$, Coftang $_{3: 22}$.

Fonem /ĺ/ bilježi se grafemom gli: vogliu ${ }_{1: 4}$, posglie $_{1: 16}$, daglie ${ }_{1: 25}$, zemgliu $_{2: 49}$, voglia ${ }_{2: 5}$, odpravgliat $_{3: 20}$, pofteglie ${ }_{5: 30}$. Kada stoji iza $g$, bilježi se 


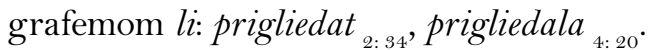

Fonem /j/ bilježi se najčešće grafemom gi: imagiuchi ${ }_{1: 5}$, gie ${ }_{1: 5}$, Divogiaftvo $_{1: 7}$, giuga $_{1: 7}$, giedan ${ }_{1: 15}$, Mattegiu ${ }_{1: 17}$, megiu $_{1: 19}$, imagiu $_{1: 21}$, giofs ${ }_{1:}$ ${ }_{28}$, nahagia $_{1: 29-30}$, giur ${ }_{1: 31}$, odfugieno ${ }_{1: 32-39}$, nimagiu ${ }_{1: 36}$, brattgia ${ }_{1: 36}$, prifsugienu ${ }_{1: 36}$, brogia ${ }_{1: 39-40}$, naregiugie ${ }_{1: 41}$, Boxgioj ${ }_{2: 4}$, govorengia ${ }_{2: 5}$, ordinugie ${ }_{2: 9}$, Staregieh $_{2: 11}$, ordinugiuchi $_{2: 13}$, nimagiu $_{2: 19}$, nigiedne $_{2: 20}$, Mattegie $_{2: 29}$, giedan ${ }_{2: 29}$, odlucugie $_{2: 32}$, priporucugiuchi ${ }_{2: 38}$, Suogiu ${ }_{2: 41}$, obogie ${ }_{2: 45}$, naregieni ${ }_{2: 47}$, ocitugie 2: 48 , pomanchangia ${ }_{2: 56}$, annulugie ${ }_{3: 9}$, trogie $_{3: 38}$, zdraugiu $_{4: 6}$, pristogieche ${ }_{4: 13}$, nahagia $_{4: 12}$, Mattegie $_{4: 14}$, zbrogie $_{4: 16}$, gnegiu $_{4: 17}$, milosergie $_{4: 7}$, uxivangie ${ }_{5: 10}$, naregiugie $_{6: 7-8}$, abubke $_{7: 22}$. Rjeđe se ovaj fonem bilježi drugim grafemima: $j$ Boxgioj $_{2: 4}$, Matteju $_{2: 17}$, Juga $_{2: 30}$, gnoj $_{2: 39}$, Mattej $_{\text {3:2 }}$, Mattej $_{3: 19}$, pervoj $_{\text {3: } 26}$ ), $i$ (naizadgnu $_{3: 4}$, Naipervo $_{3: 6}$, Suoiga $\left._{6: 11}\right)$, (odbigena $_{1: 37}$, Gellenu $_{6: 7}$, pristogi $\left._{6: 12}\right)$.

Fonem /g/ bilježi se grafemom $g h$ kako bi se razlikovao od onih mjesta gdje je $g$ uposleno za označavanje fonema /j/: dughi ${ }_{1: 21}$, draghu ${ }_{2: 36}$, drugheh 2: 44 , Drugho $_{3: 12}$, gnegha ${ }_{6: 9}$, Ghersinichia ${ }_{8: 4}$, priseghun ${ }_{8: 21}$, gha $_{7: 35}$. Premda Tomičić gotovo posve dosljedno grafemom $g h$ bilježi fonem /g/, u transkripciji je na pojedinim mjestima isti slijed pročitan kao /j/, npr. da ucinit ima za Matter po Smerte gneghe za gneghe Dussu ${ }_{1: 8-9}$.

Fonem /š/ može biti označen grafemom $\int s\left(D u s_{s}{ }_{1: 9}, M a s_{1: 9}\right.$, donafsalo ${ }_{1: 10}, M a \int_{s e} e_{1: 11}, \operatorname{gio} \int_{1: 28}$, utverdifse ${ }_{1: 42}, \operatorname{gio} \int_{s_{7: 5}}$ ), a u položajima u kojima je /̌s/ nastalo od /s/ asimilacijom po mjestu tvorbe bilježi se $s$ (puschia 1: , posglie $_{1: 16}$, nepuscheno ${ }_{1: 20}$, peschinu $_{1: 30}$, Baschinu $_{2: 28}$, Cresgne $\left.{ }_{7: 14}\right)$, no ne posve dosljedno: Suersetak $_{3: 47}$, danafsgni ${ }_{2: 6}$. Sasvim je iznimno u funkciji toga fonema grafem J: Divogiaftvo ${ }_{1: 7}$.

Tri su načina bilježenja fonema /s/. Može se bilježiti grafemom s (espone ${ }_{1: 2}$, pustil $_{1: 6}$, Sobon ${ }_{1: 19}$, Sudil $_{2: 9}$, Stvare ${ }_{2: 16}$, Staru $_{2: 32}$, Stomagne ${ }_{3: 32}$, Slusbe ${ }_{5:}$ ${ }_{20}$, prisegun $\left.{ }_{5: 34}\right), \int\left(\right.$ duxnofte $_{1: 4-5}$, iftomu ${ }_{1: 24}$, Coftagna ${ }_{1: 38}$, meftu ${ }_{2: 30}$, Nevefte ${ }_{4:}$

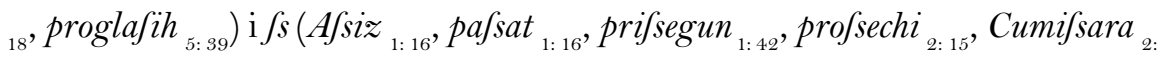
$\left.{ }_{13}, O \int s i p u_{3: 28}\right)$. Premda se ne može utvrditi potpuna dosljednost u provođenju toga načela, čini se da je drugi od tih triju grafema češći ispred dentala /t/, a treći među dvama vokalima.

Fonem / k/ može se bilježiti i grafemom $c$ : Jacova $_{1: s}$, corona $_{1: 9}$, franco $_{1:}$ ${ }_{12}$, francoga ${ }_{1: 14}$, Conobe ${ }_{\text {1: } 28}$. Tek se u jednome primjeru bilježi grafemom $q$, i to samo u primjeru Loqvice ${ }_{7: 16}$.

Grafem $u$ katkad označava fonem /v/, a grafem $v$ fonem /u/: Sue ${ }_{1: 42}$, Suu $_{2: 27}$, Suedoki ${ }_{3: 50}$, Suersetak ${ }_{5: 32} ;$ vfficij $_{1: 4}$. 


\section{2. Negovetićeva grafija}

Fonem /ć/ bilježi se najčešće grafemom ch, ali i chi: Lazarich ${ }_{9: 2}$, Vdouicich

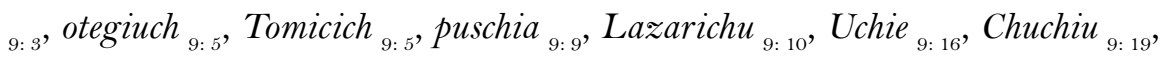
rech $_{9: 21}$, Lazarichiu $_{9: 33}$, uech $_{9: 34}$, rasu(t)chie ${ }_{9: 42}$, Negouetichia ${ }_{9: 45}{ }^{33}$ Premda se grafemom $c$ obično označava fonem /č/, u pojedinim primjerima može označavati i fonem /ć/: chuci ${ }_{9: 19-20}$. U primjeru nehie ${ }_{9: 40}$ vjerojatno je pogreškom ispušteno $c$.

Fonem /č/ bilježi se grafemom $c$ : Tomicich $_{9: 5}$, cini $_{9: 10}$, cinit $_{9: 20}$, cetireh ${ }_{9: 26}$. Grafemom z bilježi se fonem /c/: strizu ${ }_{9: 9}, O z a_{9: 15}$, intenzion ${ }_{9: 92}$, Lesizu 9: $33^{\circ}$

Fonem /̌̌/ može se bilježiti grafemima $s$ ili z: Supana $9: 7$, Gersin $_{9: 40}$, ozenila $_{9: 41}$.

Zabilježen je malen broj primjera s fonemom /ń/. U grafiji je predstavljen kao ni ili $n$ : zadniu ${ }_{9: 4}$, Sirotnaku $_{9: 10}$, zadnoj $_{9: 43}$.

Fonem /j/ bilježi se najčešće grafemima gi (uolgio $_{9: 4}$, volgie ${ }_{9: 43}{ }^{34}{ }^{34}$ ote-

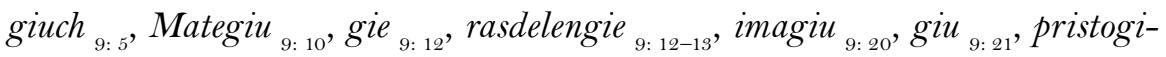
angiem $_{9: 25}$, nahagia $_{9: 25}$, rasdelengiem ${ }_{9: 41}$, Andregion ${ }_{9: 45}$, Mategion $\left.{ }_{9: 46}\right)$ i $g$

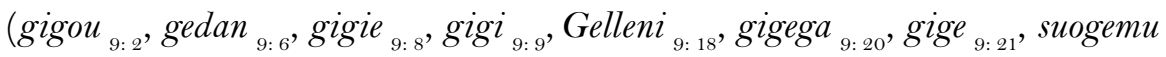
9: 24, diuogche ${ }_{9: 31}$, gednu $_{9: 33}$, ge $_{9: 34}$, gednu $\left._{9: 35}\right)$. Rjeđe se ovaj fonem bilježi grafemom $i$ : Naiperuo ${ }_{9: 12}$, gioi ${ }_{9: 12}$, meiu $_{9: 13}$. Između vokala $i$ i $e$ ne bilježi se u grafiji: priela ${ }_{9: 34}$, Lucie $_{9: 38}$.

Fonem /g/ bilježi se grafemom g: Gergur ${ }_{9: 2}$, riseg $_{9: 6}$, obligon $_{9: 30}$, Gerguron $_{9: 39-40}$, Gersin $_{9: 40}$, odgouorila ${ }_{9: 40}$, suega $a_{9: 42}$, prisegun $_{9: 44}$.

Fonem /š/ najčešće se bilježi grafemom s: prisli $_{9: 3}$, puschia $_{9: 9}$, prisal $_{9:}$ ${ }_{12}$, donasa $_{9: 29}$, Lesizu $_{9: 33}$, masit $_{9: 35}$, dusu $_{9: 36}$, nistar $_{9: 41}$, scodu $_{9: 42}$, a nerijetko i $\int_{s:}$ Vlafsinar $_{9: 2}, \mathrm{Mafs}_{9: 14}, d u \int_{s u_{9: 14}}$, utuerdifse ${ }_{9: 44}$.

Fonem /s/ bilježi se gotovo potpuno dosljedno grafemom s: smertun ${ }_{9: 3}$, tistament $_{9: 4}$, pasani $_{9: 5}$, taneh $_{9: 21}$, sue $_{9: 29}$, pustit ${ }_{9: 40}$. Posve su iznimni primjeri kao upifat ${ }_{9: 4}$ ili sufse ${ }_{9: 13}$.

Fonem / k/ predstavljen je u grafiji najčešće kao ch: chi ${ }_{9: 2}$, usroch ${ }_{9}$

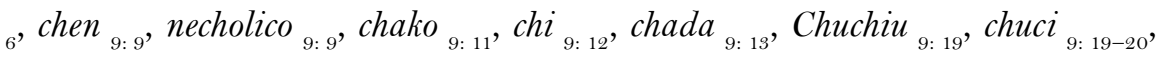

33 Budući da Negovetić potpisuje tek jednu oporuku, nema dovoljno primjera temeljem kojih bi se moglo utvrditi slijedi li i on isto načelo distribucije ovih dvaju grafema koje slijedi Tomičić (pa se odstupanja mogu smatrati slučajnim, uobičajenim nedosljednostima) ili je njihova distribucija slobodna (u tom bi slučaju nedosljednost bila svojstvena drugome notaru).

34 U objavljenoj su transkripciji (Iv. Eterović - Ig. Eterović, „Devet oporuka iz lovranske kancelarije“, 81, 83) primjeri uolgio ${ }_{9: 4}$, volgie ${ }_{9: 43}$ slučajnom omaškom pogrešno zapisani kao volju (s ispravljenom pogreškom notara), volje. Ispravna transkripcija glasi vol'ju, vol'je. 
chada $_{9: 22}$, cha $_{9: 23}$, diuogche ${ }_{9: 31}$, rechal ${ }_{9: 38}$, pochle $_{9: 38}$, uelich $_{9: 42}$, Marchulinom 9: 46. Rijetko se bilježi grafemom $c\left(\mathrm{Cus}_{9: 16}, \mathrm{Craj}_{9: 32}\right.$, usrocouala $_{9: 42}$, scodu $\left.{ }_{9: 42}\right)$, još rjeđe grafemom $k$ (usrok $\left.{ }_{9: 27}, k u_{9: 44}\right)$. Posve se iznimno na njegovu mjestu javlja grafem $h$ : suedoh $_{9: 6}$, suersetah ${ }_{9: 49}$.

Fonem /v/ vrlo je često zabilježen grafemom $u$ : ua ${ }_{9: 3}$, oue ${ }_{9: 4}$, Iuana ${ }_{9:}$

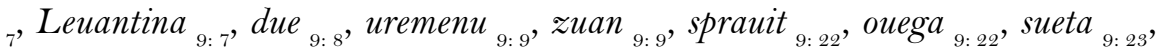
uech $_{9: 34}$, suedoki ${ }_{9: 45}$.

Fonem /z/ nerijetko se bilježi grafemom s: usroch $_{9: 6}$, rasloga $_{9: 20}$, usrok 9: 27, usrok $_{9: 34}$.

Grafijska su rješenja dvojice notara usporedno prikazana u sljedećoj tablici: ${ }^{35}$

\begin{tabular}{|c|c|c|c|c|}
\hline & \multicolumn{2}{|c|}{ Tomičić } & \multicolumn{2}{|c|}{ Negovetić } \\
\hline Fonem & Grafem & Primjer & Grafem & Primjer \\
\hline \multirow{2}{*}{ /ć/ } & $\begin{array}{c}c h \text { na kraju riječi } \\
\mathrm{i} \text { ispred } i, e\end{array}$ & $\begin{array}{c}\text { Petricich }_{5: 2}, \\
\text { hoche }_{2: 9}\end{array}$ & \multirow{2}{*}{ ch i chi } & \multirow{2}{*}{$\begin{array}{l}\text { Tomicich }_{9: 5}, \\
\text { puschia }_{9: 9}\end{array}$} \\
\hline & $\begin{array}{c}\text { chi u ostalim } \\
\text { položajima }\end{array}$ & $\begin{array}{l}\text { puschia }_{1: 6}, \\
\text { kuchiun }_{1: 7}\end{array}$ & & \\
\hline \multirow[t]{2}{*}{$/ \check{c} /$} & $\begin{array}{c}c \text { ispred } i, e ; \\
\text { rjeđe u ostalim } \\
\text { položajima }\end{array}$ & $\begin{array}{l}\operatorname{macin}_{2: 7}, z a c_{7:} \\
{ }_{7}, \text { Cresgne }_{7: 14}\end{array}$ & \multirow[t]{2}{*}{$c$} & \multirow{2}{*}{ cetireh $_{9: 26}$} \\
\hline & $\begin{array}{c}\varepsilon \text { obično na } \\
\text { početku riječi }\end{array}$ & $\varepsilon_{1: 3}$ & & \\
\hline /c/ & češće $c z$, rjeđe $z$ & $\begin{array}{c}\text { polovicz }_{7: 27} \\
\text { Sudaz }_{4: 7}\end{array}$ & $z$ & strizu $_{9: 9}$ \\
\hline$/ \check{\mathbf{z}} /$ & $\begin{array}{l}\text { najčešće } x, \\
\text { rjeđe } s\end{array}$ & $\begin{array}{c}\text { Xivel }_{2: 21}, \\
\text { presivela }_{8: 16}\end{array}$ & $s$ ili $z$ & $\begin{array}{l}\text { Gersin }_{9: 40} \\
\text { ozenila }_{9: 41}\end{array}$ \\
\hline$/ \mathrm{n} /$ & $\begin{array}{c}\text { u pravilu gn; } \\
\text { rjeđe gni (ispred } \\
\text { vokala stražnjeg } \\
\text { niza) }\end{array}$ & $\begin{array}{l}\text { Cresgne }_{7: 14}, \\
\text { zadgniu }_{5: 3}\end{array}$ & $n$, rjeđe $n i$ & $\begin{array}{l}\text { Sirotnaku }_{9: 10} \\
\text { zadniu }_{9: 4}\end{array}$ \\
\hline
\end{tabular}

35 Tablicom se teži prikazati grafijski sustav, zbog čega su zanemarena posve iznimno zastupljena ili sporadična rješenja. Uneseni su samo grafemi za koje postoji veća potvrđenost u korpusu. 


\begin{tabular}{|c|c|c|c|c|}
\hline \multirow{2}{*}{ /í/ } & $g l i$ & zemgliu $_{2: 49}$ & \multirow{2}{*}{$\begin{array}{c}\text { (nema } \\
\text { primjera) }\end{array}$} & \multirow{2}{*}{$\begin{array}{c}\text { (nema } \\
\text { primjera) }\end{array}$} \\
\hline & $l i$ iza $g$ & prigliedat $_{2: 34}$ & & \\
\hline \multirow[b]{2}{*}{$/ \mathrm{j} /$} & u pravilu gi & naregiugie $_{6: 7-8}$ & $g i \mathrm{i} g$ & $\begin{array}{l}\text { otegiuch }_{9: 5}, \\
\text { suogemu }_{9: 24}\end{array}$ \\
\hline & rjeđe $j, i, g$ & $\begin{array}{l}\text { Boxgioj }_{2: 4} \\
\text { naizadgnu }_{3: 4} \\
\text { Gellenu }_{6: 7}\end{array}$ & $\begin{array}{c}\text { vrlo rijetko } \\
i\end{array}$ & Naiperuo $_{9: 12}$ \\
\hline $\lg /$ & $g h$ & priseghun $_{8: 21}$ & $g$ & $\begin{array}{c}\text { Gergur }_{9: 2} \\
\text { odgouorila }_{9: 40}\end{array}$ \\
\hline \multirow[b]{2}{*}{$/ \check{\mathrm{s}} /$} & $\int s$ & utverdifse $_{1: 42}$ & \multirow[b]{2}{*}{$\begin{array}{l}\text { najčešće } s, \\
\text { rjeđe } \int s\end{array}$} & \multirow[b]{2}{*}{$\begin{array}{c}\text { prisal }_{9: 12}, \\
\operatorname{Ma} s_{9: 14}\end{array}$} \\
\hline & $\begin{array}{c}s \text { na mjestima /s/ } \\
>/ \check{s} / \text { asimila- } \\
\text { cijom po mjestu } \\
\text { tvorbe }\end{array}$ & puschia $_{1: 6}$ & & \\
\hline$/ \mathrm{s} /$ & $\begin{array}{c}s, \int \text { ispred } t, \rho s \\
\text { među dvama } \\
\text { vokalima }\end{array}$ & $\begin{array}{l}\text { Sini }_{1: 5}, \text { obftat } \\
{ }_{36} \text {, Duaifset } \\
6: 13\end{array}$ & $s$ & $\begin{array}{c}\text { smertun }_{9: 3}, \\
\text { Cus }_{9: 16}\end{array}$ \\
\hline$/ \mathrm{k} /$ & $k, c$ & $\begin{array}{l}\text { kako }_{1: 7}, \\
\text { Jacova }_{1: 3}\end{array}$ & $\begin{array}{l}c h, \text { rjeđe } k \\
\text { ili } c\end{array}$ & $\operatorname{chada}_{9: 13}$, \\
\hline
\end{tabular}

Tomičićevo je bilježenje dosljednije i ujednačenije, dok su u Negovetićevoj oporuci brojniji dvoznačni grafemi i višestruka rješenja. Bolja grafijska uređenost Tomičićevih oporuka upućuje na njegovo mnogo veće notarsko iskustvo.

Valja naglasiti da je na mjestu samoglasnoga /r/ u grafiji obojice notara

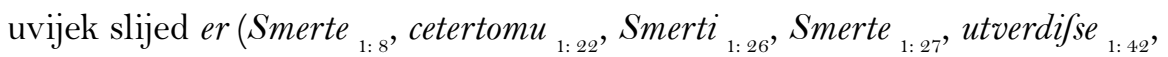
Smertun $_{2: 43}$, Bercich ${ }_{1: 44}$, Naipervo $_{3: 6}$, pervoj ${ }_{3: 26}$, Suersetak ${ }_{3: 47}$, milosergie ${ }_{4: 7}$,

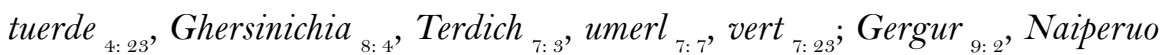
${ }_{9: 12}$, $_{\text {smerte }}^{9: 30}$, Gerguron $_{9: 39-40}$, Gersin ${ }_{9: 40}$, suersetah $_{9: 43}$, utuerdifse $\left.{ }_{9: 44}\right)$, što je zbog mogućnosti ostvarivanja toga fonema s popratnim vokalom u čakavskome narječju ${ }^{36}$ zadržano i u transkripciji. 


\section{Jezik}

\section{1. Fonologija}

Refleks je jata dosljedno ekavski u korijenskim, tvorbenim i relacijskim morfemima. U korijenskim su morfemima ekavizmi zabilježeni u sljedećim primjerima: celu ${ }_{1: 26}$, črešnje ${ }_{7: 14}, \check{c r}$ rěñi ${ }_{7: 20}, \check{c r}$ rěnju ${ }_{7: 14}$, deda ${ }_{6: 11}$, del ${ }_{9: 9}$, delile 9:13 , odelil $_{7: 17}$, podelil ${ }_{5: 27}$, razdele ${ }_{1: 18}$, razdelit ${ }_{3: 18}$, rasdelen'je ${ }_{9: 12-13}$, deca ${ }_{2: 14}$,

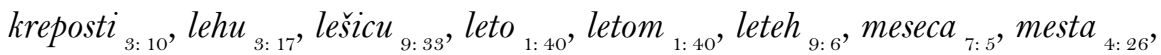
mestu $_{1: 10}$, Pě́ćinu $_{1: 30}$, pred ${ }_{1: 43}$, ponapred ${ }_{3: 18}$, sledi ${ }_{2: 8}$, nadslednici $_{2: 26}$, naslednika $_{\text {8: 9-10 }}$, postelje ${ }_{5: 30}$, sveta ${ }_{6: 5}$, sveta ${ }_{9: 23}$, telo ${ }_{2: 10}$, potrebovat ${ }_{1: 35}$, svedočanstvo ${ }_{2: 58}$, svedok $_{9: 6}$, svedokeh ${ }_{3: 7}$, svedoki $_{1: 49}$, neveste ${ }_{\text {3: } 26}$, zapovedala ${ }_{9: 38}$, vremenu ${ }_{9:}$ ${ }_{9}$. U tvorbenim su morfemima potvrđeni u sufiksu za tvorbu komparativa (starejeh $\left._{2: 11}\right)$, u infinitivnim osnovama (hotel ${ }_{2: 5-6}$, živel ${ }_{2: 21}$, razumel ${ }_{2: 49}$, imet $_{3:}$ $\left.{ }_{9}\right)$ te $\mathrm{u}$ dočetnim tvorbenim morfemima priloga (ovde ${ }_{1: 19}$, onde ${ }_{9: 25}$, pokle ${ }_{9: 38}$ ). Jednaka je refleksacija ovjerena i u relacijskim morfemima koji su imali jat u sastavu: DL jd. imenica ž. r. (D jd. Katarine ${ }_{2: 30}$, neveste $_{3: 26}$, odluke $_{3: 42}$, žene ${ }_{3:}$ ${ }_{53}$, L jd. Ike $\left.{ }_{2: 18}\right)$, L jd. imenica m. r. (grade ${ }_{2: 50}$, Lovrane $\left.{ }_{4: 1}\right)$, L mn. imenica m. i s. r. (grobeh $_{2: 10-11}$, leteh ${ }_{9: 6}$, redeh ${ }_{1: 9}$, svedokeh $\left.{ }_{3: 7}\right)$, I jd. m. i s. r. zamjeničko-pridjevske deklinacije (tem 1: 8 , ovem $\left.{ }_{4: 20}\right)$, G, D i I mn. svih triju rodova riječi sa zamjeničko-pridjevskom deklinacijom ( $\mathrm{G}$ mn. rečeneh ${ }_{1: 23}$, oneh ${ }_{1: 30}$, keh ${ }_{1: 31}$, kantaneh $_{2: 41}$, drugeh ${ }_{2: 44}$, oneh ${ }_{3: 25}$, keh ${ }_{3: 25} ; \mathrm{D}$ mn. dvem ${ }_{2: 39}$, I mn. božastvenemi ${ }_{2: 11-12}$, kemi $\left._{2: 62}\right)$. U Tomičićevim su oporukama zabilježeni i rijetki ikavizmi: jedan u korijenskome (divojaštvo ${ }_{1: 7}^{37}$ ), a drugi u tvorbenome morfemu (u prefiksu prě-: prihranit ${ }_{2: 34}$, priporučujući ${ }_{2: 38}$, priporučila ${ }_{4: 9}$ ). U Negovetićevoj je, uz primjer divojke ${ }_{9: 31}$, zabilježen i korijenski ikavizam slidi ${ }_{9: 11}$.

Rezultat vokalizacije poluglasa uvijek je vokal /a/. Zamjetna je i čakavska tendencija jake vokalnosti ${ }^{38}: v a_{1: 1}, \check{c a}_{1: 10}$, malin ${ }_{1: 38}$, malina $_{1: 14}$, Malinara 1:, , mane $\mathrm{G} \mathrm{jd.}_{1: 43}$, vazet ${ }_{3: 23}$, vazel ${ }_{6: 11}$, vazmu $_{4: 17}$, mašit ${ }_{9: 35}$, mašu $_{9: 35}$. Vokalizacija poluglasa u zamjenici $\check{c} a$ izostaje kada je ona dijelom prijedložnoga izraza: $z a \check{c}$

U Tomičića je zabilježena čakavska promjena /ę/ > /a/ iza palatala: prijah $_{5: 40}$, koja u Negovetića izostaje: prijela ${ }_{9: 34}$.

37 Unatoč dosljedno ekavskomu refleksu jata u ekavskome su dijalektu čakavskoga narječja uobičajeni leksički ikavizmi divojka, jist, tirat, šmrika, vira i njihove izvedenice. Silvana Vranić, Čakavski ekavski dijalekt: sustav i podsustavi, Rijeka 2005., 46. Uz ove se korijenske ikavizme pojavljuju i drugi u različitu omjeru. V. više u: isto, 129-130.

38 Čakavska se tendencija jake vokalnosti, između ostaloga, ogleda u provođenju vokalizacije slaboga poluglasa i u nepreventivnim položajima (v. Moguš, Čakavsko narječje, 20-21). O vokalizaciji poluglasa u slabome položaju u čakavskome narječju usp. i: Josip Lisac, Hrvatska dijalektologijja II: Čakavsko narječje, Zagreb 2009. 
U oblicima upitno-odnosne zamjenice ki dosljedno je provedena kontrakcija vokala nakon ispadanja intervokalnoga $/ \mathrm{j} /: k u_{1: 4}, k o_{1: 6}, k u_{1: 28}, k i_{2:}$ ${ }_{4}, k e_{2: 45}, k i_{3: 2}, k u_{3: 17}, k i_{4: 2}, k a_{4: 4}, k a_{5: 5}, k i_{9: 12}$. Zanimljivi su nekontrahirani oblici G jd. ž. r. lične zamjenice za 3. 1. u posvojnoj funkciji: njeje ${ }_{1: 8}$, njeje $_{1: 8-9}$.

U početnome položaju ispred vokala /i/ može se javiti protetski suglasnik /j/. Njegovo je javljanje zabilježeno u množinskim oblicima lične zamjenice za 3. 1.: jih ${ }_{3: 20}$, jih ${ }_{8: 16}$, jih ${ }_{9: 31}$.

$\mathrm{U}$ infinitivu je uvijek apokopiran završni vokal: čut ${ }_{1: 3}$, učinit ${ }_{1: 8}$, štimat se $_{1: 10}$, plaćat ${ }_{1: 11}$, platit ${ }_{1: 21}$, dat ${ }_{1: 23}$, donapunit ${ }_{1: 36}$, činit ${ }_{1: 40}$, postavit ${ }_{2: 6}$, suprotivit se $_{2: 19}$, potrebovat ${ }_{2: 20}$, prigljedat ${ }_{2: 34}$, prihranit $_{2: 34}$, prinastat $_{2: 34}$, morat ${ }_{2: 46}$, imet 3:9, prinast $_{4: 6}$, popisat ${ }_{5: 5}$, mantrat $_{7: 35}$, pravdat $_{7: 35-36}$, upisat ${ }_{9: 4 .}$. U Negovetićevoj se oporuci dočetno /i/ gubi i u aktivnome participu prezenta: otejuć ${ }_{9: 5}$.

$\mathrm{U}$ prijedlogu/prefiksu $i z / i z$ - može se reducirati početni vokal: zvan ${ }_{1}$ ${ }_{28}$, zgubit $_{3: 43}$, zvan $_{9: 9^{\circ}}{ }^{39}$

U primjeru je ustalo $_{9: 28}$ zabilježen prijelaz /o/ > /u/ u početnome položaju. ${ }^{40}$ Zamjena vokala /o/ s /u/ zabilježena je u posuđenicama, no ne provodi se dosljedno: uficij $_{1: 4}$, kumisara $_{2: 13}$, urdinal ${ }_{3: 6}$, uficij $_{5: 1}$, uficiju $_{6: 1}$, uficij $_{9:}$ , ali oficiju ${ }_{1: 1}$, oficijom ${ }_{2: 11}$, ordinal ${ }_{3: 51}$.

U slijedu /ae/ radi uklanjanja zijeva drugi se vokal zamjenjuje sonantom /j/: petnajst ${ }_{5: 29}$.

Radi slabljenja napetosti na kraju sloga provodi se zamjena šumnika

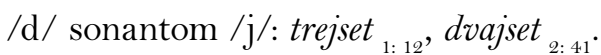

U oporukama je obojice notara zamjetno zatvaranje vokala /e/ > /i/ u oblicima posvojnih zamjenica za 3. 1., a u Negovetića su zabilježeni oblici bez inicijalnoga /n/: njigovu ${ }_{1: 3}$, njigovoj $_{1: 5}$, njigovem ${ }_{3: 14}$, njigovu $_{6: 14}$, njigovega ${ }_{8:}$ ${ }_{6}$, jigov ${ }_{9: 2}, \dddot{j i j i}_{9: 9}, \dddot{j i j i}_{9: 12}, \dddot{j i j u}_{9: 21}$, jijega ${ }_{9: 25}, \dddot{j i j e}_{9: 27}, \dddot{j i j o j}_{9: 49}$. U Tomičića se ne provodi beziznimno za sve rodove kao u Negovetića: njeju ${ }_{4: 17}{ }^{*}$

Praslavensko $* d j$ dalo je /j/: meju ${ }_{1: 19}$, nahaja $_{1: 29-30}$, odsujeno ${ }_{1: 32-39}$, prisujenu $_{1: 36}$, narejuje $_{1: 41}$, narejeni ${ }_{2: 47} ;$ meju $_{9: 13}$, nahaja ${ }_{9: 25}$. Praslavensko $*$ tj dalo je /ć/: kuća ${ }_{4: 13}$, sreća $_{5: 15}$. Praslavensko *stj dalo je /šć/: pušća ${ }_{1: 6}$, nepušćeno ${ }_{1:}$ 20, bašćinu ${ }_{2: 28}$, pušćeno ${ }_{5: 10}$.

Sekundarna jotacija nije provedena, što potvrđuju primjeri bratja ${ }_{1: 36}$, miloserje $_{4: 7}$, a dobro se čuvaju i sekundarni skupovi u glagolskim imenicama:

39 S obzirom na osjetljivost postupka transkripcije te malobrojnost i nedosljednost primjera, ne može se odrediti jesu li prijedlog $s$ i prijedlog/prefiks $i z$ ujednačeni u lik $z$.

40 Do takva prijelaza obično dolazi u prednaglasnome slogu, što se može pretpostaviti, unatoč tomu što u oporukama nisu označeni naglasci, i za ovaj primjer. 
govoren'ja $_{2: 5}$, narejen'je ${ }_{5: 6}$, pomankan'ja ${ }_{2: 56}$, razpoznan'je ${ }_{3: 28-29}$, uživan'je ${ }_{5:}$ ${ }_{10}$, rasdelen'je ${ }_{9: 12-13}$, pristojan'jem ${ }_{9: 25}$. U Negovetićevoj je oporuci međutim zabilježen i primjer rasuće $_{9: 41}$, koji sugerira provedenu jotaciju.

Finalno je slogovno /1/ neizmijenjeno: pustil ${ }_{1: 5}$, zapisal $_{1: 6}$, dal ${ }_{1: 32}$, očitoval $_{1: 32}$, hotel ${ }_{2: 5-6}$, sudil ${ }_{2: 9}$, živel ${ }_{2: 21}$, decipeval ${ }_{2: 21-22}$, fundeval $_{2: 22}$, učinil ${ }_{2: 35}$, urdinal $_{3: 6}$, suprotivil $_{3: 41-42}$, prigljedal $_{4: 8}$, prinastal $_{4: 8}$, odnel $_{5: 27}$, podelil ${ }_{5: 27}$, ere-

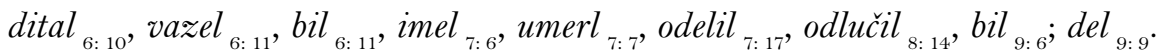

U suglasničkoj skupini u slijedu sa slogotvornim $/ \mathrm{r} /$ reduciran je sonant /v/: četertomu ${ }_{1: 22}$, Terdić $_{7: 3}$, ali tverdi ${ }_{5: 6}$. Ispred šumnika i sonanata iza kojih se našao nakon redukcije poluglasa /v/ se može vokalizirati (vazel 6:11 umerl $_{7: 7}$ ), a nedopuštena je inicijalna suglasnička skupina /vs/ dosljedno razriješena metatezom u svim primjerima, npr. svega ${ }_{7: 17}$, sve $_{7: 29}$, svem ${ }_{7: 31}$, svaki $_{7: 36}$, Svegamogući ${ }_{8: 10}$, sve ${ }_{9: 20}$, svem $_{9: 25}$.

Očuvana je skupina /čr/: G jd. črešnje ${ }_{7: 14}$, črešnjï ${ }_{7: 20}$, A jd. črešnju ${ }_{7: 14}$.

Rotacizam /ž/ > /r/ zabilježen je u prefigiranoj prezentskoj osnovi glagola moći (3. 1. jd. premore ${ }_{2: 12}$ ) i prilogu jur ${ }_{1: 31}$.

Promjena se fonema $/ \mathrm{l} />/ \mathrm{j} /$ ne provodi: zemlju ${ }_{2: 49}$, valjat $_{2: 55}$, valja ${ }_{2:}$ ${ }_{56}$, odpravljat $_{3: 20}$, postelje ${ }_{5: 30}$. Iznimka je primjer $z$ dravju $_{4: 6}$.

U Negovetićevoj je oporuci, sudeći po grafiji, zabilježen nesliven izgovor fonema /í/ u imenici voĺa: vol'ju ${ }_{9: 4}$, vol'je ${ }_{9: 49}$, što za Tomičićeve oporuke nije tipično: volja ${ }_{2: 53}$, volju $_{3: 4}$, volje ${ }_{4: 21}$.

U prefiksalnim je izvedenicama glagola $i t i$ vokal /i/ konsonantiziran $\mathrm{u} / \mathrm{j} /$ pojt $_{3: 3}$.

Ovjeren je adrijatizam /m/ > /n/, neznatno češće u Negovetićevoj oporuci: sobon $_{1: 19}$, isten ${ }_{5: 21}$, oben ${ }_{9: 16}$, obligon $_{9: 30}$, Andrejon ${ }_{9: 45}$, Matejon $9: 46$.

U Negovetićevoj je oporuci zabilježen i primjer breha ${ }_{9: 17}$, iz kojega se iščitava zamjena dočetnoga okluziva osnove $/ \mathrm{g} /$ frikativom $/ \mathrm{x} /$.

U glagolu gledati i njegovim složenicama dolazi do promjene /gl/ > /gíl: prigljedat ${ }_{2: 34}$.

U primjeru ništar ${ }_{9: 41}$ zabilježen je navezak $r$.

\section{2. Morfologija}

Morfologija imenica pokazuje konzervativno stanje u množinskim padežima, dok se u jednini starije stanje kontinuira nejednakim opsegom. U G jd. imenica ž. r. nekadašnjih a-osnova prevladava relacijski morfem /e/, preuzet iz palatalne varijante glavne deklinacije: strane ${ }_{1: 7}$, konobe ${ }_{1: 28}$, Ike 2:2 
strane $_{2: 30}$, ponjave ${ }_{3: 32}$, službe ${ }_{5: 20}$, jabuke $_{7: 22}$, sestre $_{9: 8}$, Katarine $_{9: 8}$, no zabilježen je i stari morfem /i/: strani ${ }_{3: 54}, Z_{\text {Zatki }}{ }_{7: 16}$. U NA mn. imenica ž. r. a-osnova zabilježen je samo alomorf palatalne varijante: ruke ${ }_{1: 43}$, sestre ${ }_{9: 8}$. U DL jd. imenica ž. r. relacijski je morfem /e/, podrijetlom od jata: D jd. Katarine $2: 30$, neveste $_{3: 26}$, $_{\text {odluke }}{ }_{3: 42}$, žene ${ }_{3: 53}$, L jd. Ike ${ }_{2: 18}$. Isti je morfem analogijom prodro i u D jd. nekadašnjih r-osnova: hćere ${ }_{1: 32}$, hćere ${ }_{2: 29}$, odnosno u L jd. ja- i i-osnova: kuće ${ }_{5: 20}$; dužnoste ${ }_{1: 4-5}$, smerte $_{1: 8}$, miloste $_{2: 4}$, boleste ${ }_{4: 6-7}$. U I jd. imenica ž. r. zastupljen je relacijski morfem /un/: kućun ${ }_{1: 7}$, prisegun ${ }_{1: 42}$, ženun ${ }_{5:}$ ${ }_{22}$, pa i u imenica i-deklinacije: smertun $_{2: 43}$, smertun $_{9: 3}$. U L jd. imenica m. i s. r. prevladava noviji morfem /u/, kojim se taj padež izjednačio s dativom:

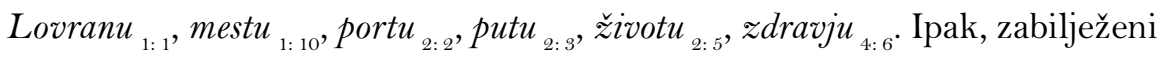
su i primjeri s morfemom /e/, podrijetlom od jata: grade ${ }_{2: 50}$ Lovrane $_{4: 1}$. U $\mathrm{N}$ mn. imenica m. r. zabilježeni su samo primjeri kratke množine: dugi ${ }_{1: 21}$, sini $_{1: 5}$. U G mn. imenica svih triju rodova zastupljen je relacijski morfem /ø/: maš ${ }_{1: 9}$, soldin ${ }_{1: 11}$, let $_{1: 11}$, libar ${ }_{1: 24}$, ovac ${ }_{1: 29}$, kostanj ${ }_{1: 30}$, brat $_{1: 35}$. Množinski padeži nisu sinkretizirani i čuvaju se arhaični nastavci: D mn. sinom ${ }_{1: 20}$, hćeram $_{2: 39}$, eredom $_{5: 18}$, sestram ${ }_{5: 27} ;$ L mn. redeh $_{1: 9}$, grobeh $_{2: 10-11}$, svedokeh ${ }_{3: 7}$, rukah $_{5: 7}$; I mn. svedoki ${ }_{1: 49}$, službami ${ }_{2: 11}$, paktami ${ }_{5: 38}$, ulikami $_{7: 11}$. Analogijski je prodor nastavka za L mn. m. r. nekadašnje o-deklinacije u sklonidbu palatalnih osnova zabilježen u primjeru dolceh ${ }_{7: 19}$.

U Tomičićevim oporukama nisu zabilježeni enklitički oblici ličnih zamjenica za 3. 1. i ž. r., već se uvijek rabe naglašeni: hćere je dal ča njoj je bilo odsujeno $_{\text {1: 32-39, }}$ ka ovomu da njoj je dal ${ }_{1: 33-34}$, budući da njoj nimaju bratja donapunit $_{1: 36-37}$, nijedan od nje rodbine ni nju hotel prigljedat ${ }_{4: 5-6}$. U pokaznim je i odnosnim zamjenicama akuzativ izjednačen s genitivom i kada se odnosi na što neživo: ovoga [tištament] ${ }_{3: 8}, \operatorname{koga}$ [tištament] $_{3: 10}, \operatorname{koga}\left[\right.$ ordin] ${ }_{3: 48}, \operatorname{kog} a$ [ordin] 7: 38 . Akuzativni oblik neličnih zamjenica u atributnoj funkciji također je izjednačen s genitivnim: sveh svojeh ${ }_{3: 33}$, keh $_{5: 23}$.

Nominativni oblik pokazne zamjenice prvoga stupnja deikse za muški rod glasi ovi ${ }_{1: 4}$, ovi ${ }_{3: 10}$, ovi ${ }_{5: 4}$, a drugoga stupnja deikse on ${ }_{2: 30}$.

U Negovetićevoj oporuci rabi se arhaičan oblik A mn. lične zamjenice za 3. 1.: je ${ }_{9: 19}, j e_{9: 20}$.

U zamjeničko-pridjevskoj deklinaciji najzanimljiviji su padeži GDLI u oba gramatička broja. Zabilježeni primjeri pokazuju da se izvorna distribucija relacijskih morfema s obzirom na dočetak osnove dobro čuva te da je prodor nastavaka palatalnih osnova sporadičan. Tako u G jd. m. i s. r. pre- 
vladava relacijski morfem /oga/ iza tvrdoga suglasnika na dočetku osnove:

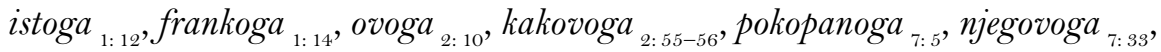
a nastavak palatalne varijante $\mathrm{u}$ istome položaju zabilježen je u primjerima njegovega $_{2: 18}$, pasanega ${ }_{6: 5}$, ovega ${ }_{9: 22}$. U D jd. m. i s. r. stanje je jednako: istomu ${ }_{1: 13}$, četertomu ${ }_{1: 22}$, ovomu ${ }_{1: 24}$; njegovemu $_{3: 48}$. U I jd. m. i s. r. tvrdih osnova relacijski je morfem /em/, gdje je /e/ podrijetlom od jata: tem ${ }_{1: 8}$, ovem ${ }_{4: 20}$; dok je u mekim osnovama /im/: njim ${ }_{7: 14}$. Iznimka je primjer takovemu ${ }_{8: 14}$, u kojem je lokativni oblik izjednačen s dativnim, dok se u ostalim primjerima razlika među nastavcima tih dvaju padeža dobro čuva. U množinskim su padežima ovjereni relacijski morfemi nepalatalnih osnova, s ekavskom zamjenom jata. U G mn. m. i ž. r. zabilježen je relacijski morfem /eh/: sveteh ${ }_{1: 9}$, rečeneh ${ }_{1: 29}$, oneh ${ }_{1: 30}$, pisaneh ${ }_{1: 39}$, kantaneh ${ }_{2: 41}$, njegoveh ${ }_{3: 41}$, maleh ${ }_{8: 19}$, staneh 9: 14, drugeh ${ }_{9: 17}$. U D mn. m. r. zastupljen je morfem /em/: pisanem ${ }_{1: 20}$. U I mn. ž. r. očuvan je stari nastavak: božastvenemi ${ }_{2: 11-12}$, kemi $_{2: 62}$. Razlika se u deklinaciji između određenoga i neodređenoga lika pridjeva ne čuva u kosim padežima: G jd. m. i s. r. pokopanoga ${ }_{7: 5}$, njegovega magazina ${ }_{2: 18}$, njegovemu tištamentu $_{3: 48}$.

Po zamjeničko-pridjevskoj deklinaciji sklanjaju se i brojevi dva, tri i četiri. Svaki se od njih rabi uz množinu: $\mathrm{N}$ mn. četiri sini ${ }_{1: 5}, \mathrm{G} \mathrm{mn}$. četireh ma ̌s $_{9: 26}, \mathrm{D}$ mn. trim sinom ${ }_{1: 20}$, dvem hćeram ${ }_{2: 39}$, dvem sestram $_{9: 16}$, A mn. četiri sini $_{1: 41}$, tri sini ${ }_{2: 26}$.

Posvojnost se za treće lice može izraziti ličnom zamjenicom u genitivu ili posvojnom zamjenicom: njega ženu ${ }_{1: 25}$, njega sini ${ }_{1: 27}$, njega eredi ${ }_{1: 42}$, njega volju $_{2: 6-7}$, njega telo ${ }_{2: 10}$, njega starejeh ${ }_{2: 11}$, njega bašćinu ${ }_{2: 27-28}$, njega eredi ${ }_{2: 33}$, njega smertun $_{2: 43}$, njega sina ${ }_{3: 19}$, njega malin ${ }_{3: 27}$, njega žene ${ }_{5: 19}$, njega blago ${ }_{6:}$ ${ }_{9-10}$, njega deda ${ }_{6: 11}$, njega hći ${ }_{8: 12-19}$, smerte njeje ${ }_{1: 8}$, njeje dušu ${ }_{1: 8-9}$, nje smerti ${ }_{1: 26}$, nje rodbine ${ }_{4: 5}$, njih bratu ${ }_{1: 22}$, njih matere ${ }_{5: 29}$; dugi njegovi ${ }_{1: 21}$, malin njegov $_{1: 38-39}$, kuća njegova ${ }_{2: 12}$, njegovega magazina ${ }_{2: 18}$, njegova žena ${ }_{2: 33}$, njegovi eredi $_{3: 33-34}$, njegovemu tištamentu ${ }_{3: 48}$, dušu njegovu ${ }_{3: 16}$, njigovu intencion ${ }_{6: 14}$, njegovoga ereda $_{8: 9}$, blaga njegovoga ${ }_{7: 18}$, blago njegovo ${ }_{7: 29}$, njegovoga žitka ${ }_{7: 33}$, njenega $_{4: 12}$, robu njeju ${ }_{4: 17}$, jijoj zadnjoj vol'je ${ }_{9: 43}$, korist njihovu ${ }_{2: 15-16}$. Prvi je način znatno češći.

S obzirom na karakter oporuke kao isprave od glagolskih su oblika najbolje potvrđeni prezent (3. 1. jd. opravi ${ }_{1: 16}$, pošlje ${ }_{1: 16}$, pušća $_{1: 20}$, narejuje ${ }_{1:}$ ${ }_{41}$, $_{\text {ordinuje }}{ }_{2: 9}$, hoće ${ }_{2: 9}$, imenuje $_{2: 19}$, veli ${ }_{2: 19}$, se nahodi ${ }_{7: 31}$; 3. 1. mn. razdele ${ }_{1: 18}$, vazmu $_{1: 27}$, govore $_{1: 31}$ ) i perfekt (je bilo ${ }_{1: 32}$, je očitoval ${ }_{1: 32}$, je dal ${ }_{1: 32}$, hotel je ${ }_{2:}$ 
${ }_{5-6}$, ni hotel $_{4: 5}$, je prinastal ${ }_{4: 8}$, je dobila ${ }_{4: 18}$, je eredital ${ }_{6: 10}$, je umerl ${ }_{7: 7}$, su prišli 9:, je prïjela ${ }_{9: 34}$, je zapovedala ${ }_{9: 38}$, pustil je $\left.{ }_{\text {passim }}\right)$. Uz njih su zabilježeni aorist (proglasih $_{5: 39}$, utverdiše ${ }_{6: 16}$, utverdiše $\left.{ }_{9: 44}\right)$, imperfekt (pisah ${ }_{2: 60}$, proptah ${ }_{2: 61}$ ), pluskvamperfekt (je bil pustil ${ }_{1: 6}$, je vazel bil ${ }_{6: 11}$ ), futur prvi (3. 1. mn. hote morat $_{2: 46}$; u Negovetića i 3. 1. jd. bude sudit!), futur drugi (donašalo bude ${ }_{1: 10}$ ), kondicional prvi (bi sudil ${ }_{2: 9}$, bi živel ${ }_{2: 21}$, bi fundeval ${ }_{2: 22}$, bi hotel ${ }_{3: 37}$, bi mankalo $_{3: 47}$, bi prišla ${ }_{5: 20}$, bi preživela ${ }_{8: 16}$, bi pustila $\left.{ }_{9: 39}\right)$ i kondicional drugi (bi bil nastal $_{9: 27}$, bi bilo ustalo $\left.{ }_{9: 28}\right)$. Imperativ je zabilježen samo u konstrukcijama 3. 1. jd. vazet imej ${ }_{3: 23}$, mozi pustit ${ }_{3: 55}$, dok se na svim drugim mjestima u značenju imperativa rabi konstrukcija prezent glagola „imati“ + infinitiv pri iskazivanju oporučiteljevih naloga: 3. 1. jd. učinit ima ${ }_{1: 8}$, štimat se ima ${ }_{1: 10}$, ima činit $_{1: 40}$, dat mu se nima ${ }_{2: 23}$, platit ima ${ }_{3: 24}$, prebivat ima ${ }_{5: 21}$, ima pustit ${ }_{7:}$ ${ }_{34}$; 3. 1. mn. platit imaju ${ }_{1: 21}$, dat imaju ${ }_{1: 23-24}$, se nimaju suprotivit se $_{2: 19}$, imaju prinastat $_{2: 34}$, razdelit imaju ${ }_{3: 18}$, odpravljat imaju ${ }_{3: 20}$, nimaju mantrat ${ }_{7: 35}$, imaju činit $_{9: 20}$, imaju spravit ${ }_{9: 22}$. Od participa su zastupljeni aktivni particip prezenta, aktivni particip preterita drugi te pasivni particip preterita. Aktivni particip prezenta rabi se u priloškoj funkciji (imajući ${ }_{1: 5}$, ordinujući ${ }_{2: 13}$, proseći 2:15, živući ${ }_{2: 35}$, priporučujući ${ }_{2: 38}$ ), osim participa budući, koji je potvrđen i u vezničkoj (budući bili zvani ${ }_{1: 2-3}$, budući da njoj nimaju bratja donapunit ${ }_{1: 35-36}$, budući bili prizvani $\left.{ }_{3: 2-3}\right)$.

Fonološke značajke vezuju oporuke uz sjevernočakavski prostor, i to, preciznije, područje čakavskoga ekavskoga dijalekta, koji se nalazi u osnovi jezika kojim su pisane. S takvom se lokalizacijom poklapa i velika jezična konzervativnost na morfološkoj razini, također svojstvena navedenomu prostoru. Iako se jezik kojim su pisane zasigurno ne može poistovjetiti s tadašnjim lovranskim idiomom (ili idiomima), ostaje činjenicom da je u jeziku očuvano mnogo arhaičnosti, zbog čega oporuke mogu biti polazištem i za povijesnodijalektološka istraživanja.

\section{Struktura}

Tri su osnovna dijela oporuke, kao i svake (notarske) isprave, protokol, korpus i eshatokol. Protokol se često sastoji od invokacije, datacije (vremenske i zemljopisne) i ponekad navođenja svjedoka. Korpus se inače u oporukama sastoji od navođenja autora oporuke (oporučitelja, testatora), nasljednika (legata) te pravne formule vezane uz izvršenje oporuke. U eshatokolu 
oporuka inače stoje datacija, notarski potpis i notarski znak te navođenje svjedoka. $^{41}$

Mnoge isprave nemaju sve navedene formule, a osim toga njihov je redoslijed različit od isprave do isprave. Neke su pak formule tipične samo za privatne isprave, u koje spadaju i oporuke. ${ }^{42}$ Oporuke načinjene u lovranskoj kancelariji načelno posjeduju ujednačenu i kontinuiranu strukturu kroz duže razdoblje. Sve su analizirane oporuke pisane u objektivnoj formi, tj. tako da ih je notar sastavljao u trećem licu. ${ }^{43}$

\section{1. Protokol (uvod)}

$\mathrm{U}$ analiziranih devet oporuka invokacija potpuno izostaje, a u naslovu (prvi redak izdvojen većim razmakom) dolazi uvijek datacija - vremenska i zemljopisna. Sve se oporuke vremenski datiraju izrazom $v$ dan, nakon čega slijedi navođenje dana (brojkom), mjeseca (riječima) i godine (brojkom). Na jednoj je od oporuka (7) zabilježen i datum njezina kasnijega izvršenja, pa su navedena dva datuma. Zemljopisna je datacija u većini oporuka $(1,5,6,8$ i 9) iskazana izrazom u Lovranu va uficiju (kančilerije), a u tri (3, 4 i 7) navedeno je $u$ Lovranu $^{44}$. Samo je jedna oporuka (2) posebno zemljopisno datirana: sastavljena je $u$ teritoriju lovranskem va portu od Ike ${ }_{2: 1-2}$.

Nakon datacije beziznimno se navode izvršitelji oporuke, osim u jednoj oporuci (2), gdje se prije toga opisuju okolnosti njezina nastanka (zbog bolesti oporučitelja sastavljena je izvan kancelarije, kod samoga oporučitelja). Svjedoci se nikad ne navode u protokolu, već dolaze na samom kraju oporuke. $^{45}$

41 Usp. Marija Karbić - Zoran Ladić, „Oporuke stanovnika grada Trogira u Arhivu HAZU“ (dalje: „Oporuke stanovnika grada Trogira“), Radovi Zavoda za povijesne znanosti HAZU u Zadru, 43, 2001., 164. Opširnije v. u: Stipišić, Pomoćne povijesne znanosti u teoriji i praksi, 150-153 i Ladić, Last Will, 75-77.

42 Usp. Stipišić, Pomoćne povijesne znanosti u teoriji i praksi, 153.

43 O načinima sastavljanja isprava v. u Grbavac, Notarijat na istočnojadranskoj obali, 90.

44 Treba napomenuti da je jedna od tih triju oporuka anulacija (poništenje) jedne prethodne oporuke, a jedna potvrda/prijepis ranije sastavljene isprave pa se vjerojatno nije smatralo potrebnim ponovno navoditi mjesto sastavljanja.

45 Ni jedna oporuka ne započinje ni verbalnom (zazivanje svetih osoba) ni simboličkom invokacijom (znak križa), sve su datirane modernim stilom, a mjesto sastavljanja oporuke navodi se kod same vremenske datacije, što pokazuje određene sličnosti s uvriježenom praksom u nekim drugim komunama, primjerice Rabu. Usp. Grbavac, Notarijat na istočnojadranskoj obali, 103-104, 114-115, 131. 


\section{2. Korpus (sadržaj)}

Iako bi se prema diplomatičkim uzusima ${ }^{46}$ ali i prema uobičajenoj praksi toga doba u drugim krajevima, ${ }^{47}$ osoba za koju se sastavlja, bilježi ili zapisuje oporuka - oporučitelj - trebala navesti u uvodnome dijelu (intitulatio), u analiziranim se oporukama iz Lovrana često zamjenjuje mjesto njezina navođenja objavom sadržaja isprave (promulgatio) i opisima okolnosti u kojima je isprava nastala (narratio). U početku središnjega dijela oporuke kombinira se navođenje oporučitelja s objavom sadržaja oporuke, a to je poziv da se čuje oporučiteljevu (naj)zadnju volju (ordin i tištament), što je beziznimno zastu-

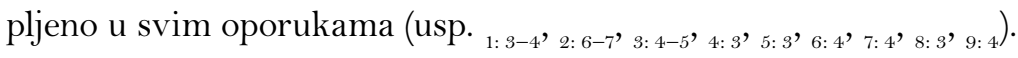

Opis okolnosti nastanka oporuke dolazi u početku središnjega dijela u sklopu objašnjenja podjele nasljedstva i nasljednih obveza. U jednoj se oporuci spominju zdravstvene okolnosti koje su nagnale oporučitelja da što prije sastavi oporuku (usp. 2:4-6), u drugoj se govori o poništenju prethodno sastavljene oporuke (usp. 3: $7-11_{1}$ ), u trećoj se navode razlozi zašto ništa nije ostavljeno rodbini već je nasljednik netko treći (usp. ${ }_{\text {4: 4-10 }}$ ), u četvrtoj se objašnjava kako je oporučitelj već prije sastavio jedno pismo s oporučnim odredbama koje sad želi potvrditi (usp. ${ }_{5: 5-10}$ ), u nekima se govori o posrednu zapisu posljednje volje preminuloga oporučitelja (usp. ${ }_{6: 5-6}$ 7: $_{\text {: } 4-5}$ ), a u jednoj se pak oporuci navode podaci o odbijanju prethodnoga notara da sastavi oporuku zbog nevjerodostojnih svjedoka (usp. ${ }_{9: 5-6}$ ).

Iza toga slijedi najvažniji dio isprave, sama „bit oporuke - raspodjela imovine i uvjeti raspolaganja ${ }^{{ }^{48}}$, tzv. dispositio ${ }^{49}$. U oporukama se nasljedstvo (imovina) ostavljalo djeci oporučitelja, no često s posebnom naznakom o tome da gospodarstvom ima upravljati žena oporučitelja do svoje smrti ili ponovne udaje (npr. ${ }_{1: 25-26}$, 2: $36-40_{3}$, 3:12-14, $_{\text {6: 6-7 }}$ ), a posve iznimno majka oporučitelja, nakon čije smrti žena postaje gospodarica imanja $\left({ }_{8: 4-8}\right)$. Glavni su nasljednici (formulom univerzal eredi) najčešće sinovi oporučitelja $\left(_{1: 41-42}\right.$, 2: 25-26, 3: 33-34), odnosno u jednom slučaju, gdje je jedan od sinova umro, u glavne je nasljednike uključena i sirota sinova obitelj (usp. 7: $7-9_{9}$ ). Kao glavni nasljednici spominju se i kćeri oporučitelja $\left({ }_{6: 8-9}\right)$ ili neka treća osoba izvan obitelji (usp. ${ }_{\text {4: 21-22, }},{ }_{5: 22-23}$ ). Ponekad se nasljedstvo uvjetuje brigom za braću

46 Usp. Stipišić, Pomoćne povijesne znanosti u teorïi i praksi, 151.

47 Sivrić, Oporuke Kancelarije stonskog kneza, 71.

48 Isto, 72 .

49 „Dispositio je s obzirom na pravni čin najvažniji dio isprave jer sadrži materijalni ili moralni objekt koji se daje destinataru." Stipišić, Pomoćne povijesne znanosti u teoriji i praksi, 151. 
- drugu oporučiteljevu djecu $\left(_{3: 45-47}\right)$, odnosno majku oporučitelja $\left({ }_{2: 32-35}\right)$, da bi i ti članovi obitelji bili osigurani.

Treba dodatno istaknuti da se u nekim oporukama pojavljuju pojedine pravne formule, ali su one više iznimke negoli pravilo. Tako možemo iščitati nekoliko finalnih klauzula, odnosno iskaza koji su u funkciji takvih klauzula. ${ }^{50}$ Kao clausula praeceptiva, formulu kojom se posebno naglašava zapovijed za izvršenjem dispozicije, možemo primjerice čitati iskaze u oporuci 2: ordinuje $i$ hoće $_{2: 9}$, veli $i$ ordinujući imenuje ${ }_{2: 13}$, veli $i$ ordinuje $i$ narejuje ${ }_{2: 25}$, veli,

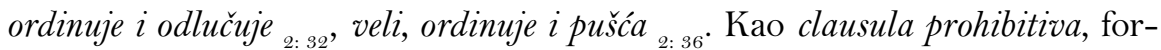
mulu kojom se zabranjuje činjenje čega što bi spriječilo izvršenje dispozicije, možemo primjerice čitati sljedeće iskaze: $i$ zato da potrebovat nima odi brat stvari nijedne ${ }_{1: 34-35}$, da bratja potrebovat nimaju od brata Mihca nijedne stvari 3: 51-52. Kao clausula derogativa, formulu kojom se oduzima pravo pozivanja na neki suprotni prethodni akt, možemo čitati iskaz u oporuci 3 kojim se anulira prethodno sastavljena oporuka (1): da rifere da ovoga anuluje posvema $i$ da hoće da nima imet nikakove kreposti, nego samo ovi, koga sada iznova njim je urdinal da rifere $_{\text {3:8-11. }}$. Zasvjedočene su i tri sankcije (sanctio), formule kojima se izriče kazna onima koji bi spriječili izvršenje dispozicije: er ako bi fundeval $i$ decipeval, ordinuje da dat mu se nima stvari nijedne, van samu legitimu ${ }_{2: 22-24}$, zatim ako ki od njegoveh eredi bi se suprotivil ovoj njega odluke, da za pervi put platit ima pene libar 10, a za drugi da zgubit ima njega del i samo da dat mu se ima legitima $_{3: 41-44}$ te da ga nimaju mantrat, ni pravdat, da pače svaki takov da izgubit ima parat njemu pušćen ${ }_{7: 36-37}$. Oporukom se dakle uvjetovalo ponašanje nasljednika, i to ne samo odnos prema ostalim članovima obitelji već i ponašanje nasljednika samih u raspolaganju imovinom.

\section{3. Eshatokol (zaključni dio)}

Formula koroboracije (corroboratio), kojom autor najavljuje sredstva i način kojima pravnom činu osigurava pravni učinak, trajnost i svjedočanstvo, gotovo je u svim oporukama dosljedno provedena. ${ }^{51}$ Sadržaj je korobora-

50 V. opširnije u: isto, 152 .

51 Usp. na ist. mj. Stipišić koroboraciju stavlja u središnji dio isprave, iako ističe da i elementi u zaključnom dijelu (pečat, potpisi...) imaju koroborativnu funkciju. Međutim u oporukama je, što pokazuje i M. Sivrić za druge prostore u ovom razdoblju (Sivrić, Oporuke Kancelarije stonskog kneza, 86-87), koroboraciju ipak opravdano svrstavati u zaključni dio oporuke. 
cije raznovrstan: pozivanje na obvezu univerzalnih nasljednika ${ }^{52}$ i njihova prisega, a pred samim notarom i svjedocima (usp. 1:42-44 $_{\text {, }}$, izjava notara da je sve napisao tako moljen od oporučitelja $\left({ }_{2: 60-63},{ }_{5: 37-40}\right)$, isticanje da je to kraj oporučiteljeve posljednje volje utvrđen s prisegom pred samim notarom i

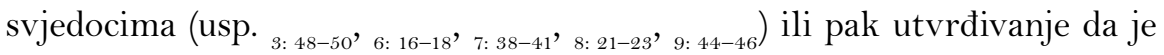
sam notar sve napisao pred svjedocima $\left({ }_{4: 23-26}\right)$.

Tri oporuke koje je ovjerio Anton Tomičić imaju autografski potpis notara $\left({ }_{1: 43,44}, 2_{58},{ }_{5: 40}\right)$, a tri sadrže i notarski pečat (pečat kancelarije), na samome vrhu u lijevoj margini isprave $(1,2,4) .{ }^{53}$ Samo dvije sadrže istodobno i potpis i pečat $(1,2)$, dok jedna sadrži samo potpis, a jedna samo pečat. To može donekle čuditi jer su upravo notarov potpis i pečat bili u funkciji koroboracije u ispravi, tj. oni su pravnom činu osiguravali valjanost, ${ }^{54}$ no u primorskim gradovima „uz bilježničku ovjeru pečaćenje nije ni u kakvoj vrsti listina neophodna potreba za njihovu pravnu dokaznu snagu“ “55, već se oni pojavljuju „uvijek samo kao sekundarni pratioci ovjere bilježnika.“ ${ }^{56}$

Što se podataka o samome notaru tiče, tek je navedeno kančiler ${ }_{1: 49},{ }_{3: 49}$, 6: 17 7: 99, 8:22, 9:44 ili kančiler od mesta ${ }_{4: 26}$, a tek dvije oporuke imaju izdvojen podatak o notarskom činu, grafički izdvojen u posebnim recima, za pola dužine teksta oporuke u desnom donjem uglu: Anton Tomičić, kančiler od mesta, tako prošen od teštadura pisah i pred njim $i$ svedoki proptah, pred kemi utvrdil je sve kako zgora $_{2: 59-63}$ te Anton Tomičić, kančiler od mesta, tako prošen pisah i pred paktami $i$ svedoki proglasih $i$ prisehu prijah ${ }_{5: 36-40}$.

Posebno se pak izdvaja oporuka 2 kao tipičan primjer isprave čiji završetak „tvori kodicilijarna klauzula, a to je očitovanje da se posljednja volja,

52 Univerzalni nasljednik je „univerzalni sukcesor, on nasljeđuje i stječe prava i obveze neposredno i u trenutku testatorove smrti. Kasnijim pravnim postupcima u dokaznom procesu valjanosti oporuke, nasljedniku se i formalnopravno utvrđuju testamentarna prava i omogućuje njihovo stvarno korištenje.“ Sivrić, Oporuke Kancelarije stonskog kneza, 86. Univerzalni nasljednici „obično nasljeđuju najveći dio oporučiteljevih dobara, što znači sve od njegovih bona mobilia et immobilia/stabilia koja su ostala nedistribuirana." Ladić, Last Will, 77.

53 Mnoge su oporuke u istome fondu označene notarskim pečatom (pečatom kancelarije), a na mnogima je ujedno vidljiv i žig kojim su poruke bile zapečaćene (zatvorene voštanim žigom u koji se utiskivao pečatnjak). Tu treba spomenuti, nastavljajući se na prethodno istaknute utjecaje različitih notarskih praksi, „da je pečaćenje kao i pečat (žig) nasljede običaja karolinške kancelarije odnosno kancelarije njemačkih careva." Šufflay, Dalmatinsko-hrvatska srednjovjekovna listina, 89. Pečati o kojima se ovdje govori jasno su vidljivi na faksimilima objavljenima u sklopu Iv. Eterović - Ig. Eterović, „Devet oporuka iz lovranske kancelarije“, 47, 48, 52 .

54 Usp. Karbić - Ladić, „Oporuke stanovnika grada Trogira“, 166; Stipišić, Pomoćne povijesne znanosti u teoriji i praksi, 162.

55 Šufflay, Dalmatinsko-hrvatska srednjorjekovna listina, 92.

56 Isto, 89 . 
ako se zbog nedostatka ne može održati kao oporuka, mora smatrati kao kodicil." ${ }^{57}$ Ona glasi: $i$ ako ne bi mogal valjat kako tištament radi kakovoga pomankan' ja iliti solenitadi, hoće da valja kako kodicil iliti donation causa mortis takozvani ${ }_{2: 55-57^{\circ}}{ }^{58}$

Na samom kraju teksta sve oporuke (izuzev dviju spomenutih u kojima je posebno izdvojen podatak o notarskom činu, koji slijedi nakon navođenja svjedoka) imaju navedene svjedoke pravnoga čina uz izraz pred svedoki ${ }_{1: 43-44}$, 3: 49-50, 4: 24-25, 5: 34-35, 6: 17-18, 7:40-41, 8: 22-23, 9:45-46 ili na svedočanstvo ${ }_{2: 58}$.

\section{Sadržaj}

\section{1. Vrste oporuka i osobe nazočne pri sastavljanju oporuka}

Količina sačuvanih oporuka iz lovranske kancelarije, a možemo naslućivati da je to tek jedan dio, svjedoči nam o razvijenu običaju sastavljanja oporuka na području Lovrana u 18. i 19. stoljeću. Tomu u prilog govori i činjenica da su oporuke pisane i kada nije bila riječ o nekoj značajnijoj imovini (npr. oporuka 8), već se samo u nekoliko redaka teksta želi jasno potvrditi koja je posljednja volja oporučitelja u pogledu upravljanja imanjem nakon njegove smrti.

Već su i na ovome manjem korpusu vidljive dvije vrste pisanja oporuka: oporuke u užem smislu i brevijariji. Prve se odnose na oporuke napisane za oporučiteljeva života. Zanimljivo je da ni jedna oporuka nije vlastoručno napisana od oporučitelja. To može govoriti o jedinstvenoj praksi lovranske kancelarije, ali jednako tako i o nepismenosti oporučitelja. Tek je jedna oporuka (2) nastala sa sigurnošću pred samim oporučiteljem, i to vjerojatno u njegovu skladištu u ikarskoj luci.

Za sve ostale oporuke navodi se da ih prenose izvršitelji ${ }^{59}$, a prema volji oporučitelja, no nije jasno je li i sam oporučitelj prisutan u trenutku bilježenja oporuke $(1,3,4,5,8)$. Ako je suditi po oporuci 2 , u kojoj je očita prisutnost oporučitelja, a gdje nisu navedeni izvršitelji, već samo svjedoci, vrlo je vjerojatno da u posljednjim oporukama nisu bili prisutni oporučitelji te da je riječ o brevijarïima. Brevijariji su se sastavljali kao „naknadno bilježenje

57 Isto, 128 .

58 Iako Margetić navodi da je kodicil odredba posljednje volje koja, za razliku od oporuke, ne može sadržavati imenovanje nasljednika (Margetić, Hrv. srednjovj. obiteljsko i nasljedno pravo, 36), kodicil naprosto treba shvatiti u općenitom smislu - jednostavno kao dopunu ili izmjenu testamenta (oporuke). Usp. npr. Grbavac, Notarijat na istočnojadranskoj obali, 88 i Grbavac, „Notarska služba i komunalno zakonodavstvo“, 63.

59 Interesantno je da oni nisu nikako posebno naznačeni ili nazvani, već se samo navodi da se pojavljuju pri izradi oporuke (kompare). Po svojoj funkciji to jedino mogu biti povjerljivi muškarci, povjerenici nadležni za izvršenje oporuke, a koji su se različito nazivali u raznim područjima: od povjerenja (manufidelis), izvršitelj (executor), testamentar (testamentarius), povjerenik (comissarius) ili epitrop (epitropus). Šufflay, Dalmatinsko-hrvatska srednjovjekovna listina, 128. 
posljednje volje osobe koja nije iz nekog razloga mogla sastaviti redovnu oporuku pred notarom. Zapisivanje se tada vršilo putem izjava svjedoka“" ${ }^{60}$

U punom su smislu brevijariji, dakle odredbe posljednje volje učinjene poslije oporučiteljeva života, a preko usmene izjave izvršitelja i pred svjedocima, tri oporuke $(6,7,9)$. Prva je načinjena 19 dana nakon oporučiteljeve smrti, a u drugoj je naznačeno da je oporučitelj pokopan još u prošlom mjesecu. U trećoj se oporuci navodi da je načinjena dan nakon oporučiteljičine smrti.

Sve su, osim jedne (2), oporuke načinjene preko izvršitelja koji su bili pozvani od oporučitelja da iskažu njihovu posljednju volju. Njih je uglavnom dvoje, a tek iznimno troje: u prvoj Tome Antić i Anton Pleteničić ${ }_{1: 2}$; u anulaciji te oporuke umjesto Pleteničića pojavljuje se Matej Kožulić $3: 2$; Jure Žiganto $_{4: 2}$; Andrea Petričić i Mattio Palmić ${ }_{5: 2}$; Anton Palmić Meštrić i Ivan Kružić Antić ${ }_{6: 3-4}$; Lovre Valjić, Ivan Terdić i Tomaso Pičić $7: 3$; Jure Zahej i Mate Pahić 8: 2 te Martin Lazarić Vlašinar i njegov sin Gergur 9: 2 . To nam govori o pravnoj praksi da je za izvršenje oporuke bilo potrebno najmanje dvoje izvršitelja koji prenose volju oporučitelja, napose kada on nije u mogućnosti osobno prisustvovati sklapanju oporuke. Riječ je bila najvjerojatnije o pouzdanim osobama, a na to upućuje i naznaka da je jedan od izvršitelja (A. Petričić) bio sudac. Vrlo je važno naglasiti ipak da je pri sastavljanju oporuke 2 oporučitelj imenovao svoga izvršitelja ili, kako ga on naziva, povjerenika (kumisara), nadležna za izvršenje oporuke. Riječ je o sucu Mati Kumariću (2:13-15).

Svjedoka je obvezno bilo dvoje, što je dosljedno u svim oporukama: Juraj Berčić i Lorenzo Bermberić ${ }_{1: 44}$; Michelle Mičetić i Dizma Mušić ${ }_{2:}$ ${ }_{58}$; Ivan Keršanac i Mate Kružić ${ }_{3: 50}$; Anton Priskić i Anton Curella 4: 24-25; Ivan Perišić i Gergo Dobrec Škvarić ${ }_{5: 35}$; Jakov Kružić i Juraj Martinčić ${ }_{6: 18}$; Mattio Skocanić i Anton Priskić ${ }_{7: 40-41}$; Dizma Mušić i Lovre Valjić ${ }_{8: 22-23}$ te Andrej Cupar i Matej Markulin 9:45-46.

Oporuka Frančeska Palmića (5) predstavlja potvrdu nekoga ranije sastavljena pisma, vrlo vjerojatno dispozicije pisane kao nacrt za oporuku, ${ }^{61}$ uz male izmjene. Taj je prethodno napisan nacrt sastavio arčipret Peršić, tj.

60 Grbavac, Notarïat na istočnojadranskoj obali, 89. Više o brevijariju v. u Grbavac, „Notarska služba i komunalno zakonodavstvo“, 64.

$61 \mathrm{Na}$ činjenicu da se ponekad sastavljao nacrt za oporuku upućuje i dispozicija pisana hrvatskim jezikom pronađena također u ovom fondu (v. bilj. 4). 
istaknuti svećenik lovranskoga kaptola. ${ }^{62}$

Naravno, pri sastavljanju su oporuka prisutni i njihovi sastavljači kancelari A. Tomičić (1-8) i B. Negovetić (9).

\section{2. Oporučitelji, nasljednici i legati (ostavinske odredbe)}

U dvjema je oporukama oporučitelj žena (4 i 9), a u ostalima muškarac. Podaci o oporučiteljima vrlo su oskudni i za daljnje informacije o njima treba posegnuti u druge izvore (u prvome redu matične knjige). Nasljednici se razlikuju ne samo po spolu već i po tipu rodbinske povezanosti. Oporučuju se i pokretnine i nekretnine, a ta je imovina nasljednicima različito dijeljena, različite su i vrijednosti pojedinih imovina zabilježenih u oporukama te uvjetujuće odredbe nasljednicima. Sve je te osobitosti najprimjerenije razmotriti u analizi svake oporuke pojedinačno.

Prva i treća oporuka u uskoj su vezi: treća je anulacija prve i iznova utvrđena posljednja volja oporučitelja. Oporučitelj Jakov Malinar Fratar mijenja posljednju volju iz prve oporuke, ali samo u pojedinim segmentima. Blago, koje se najvjerojatnije odnosi na određeni dio imetka ${ }^{63}$, nije sada dobio sin Miho, već žena da raspolaže njime kako je njoj drago, a za divojaštvo, odnosno ako ostane divojka, u ovom slučaju dakle udovica. Poremetila se prvotna raspodjela legata među sinovima: Miho je najviše izgubio dobivši trećinu cijele ostavštine, dok je u prvotnome ostavinskom aranžmanu imao sam polovicu svih dobara. Ivanu je pak ionako malen udio u ostavštini smanjen još i više. Josip je izgubio udio u mlinu, dok je Matej prošao najbolje u svim legatima. Naposljetku treba dodati da je druga oporuka za razliku od prve mnogo sustavnije organizirana s doslovnim obrojčivanjem legata i navođenjem u zasebnim odlomcima. ${ }^{64}$

62 Arčipret (tal. arciprete) je „isto što i arhiprezbiter“, odnosno „prvi među prezbiterima; u starini prvi pomoćnik biskupov u pastoralnoj i liturgijskoj službi; uz arhiđakona stup u strukturi dijecezanskog klera; dostojanstvenik u kaptolu, postavljen nad nekoliko dekanata“. Jeronim Šetka, Hrvatska kršćanska terminologija, Split 1990., 33, 34.

63 Imetak se još na temeljima rimskoga prava dijeli na res mobiles (pokretne, pokretnine), res immobiles (nepokretne, nekretnine) i res se moventes (životinje). V. Grbavac, Notarijat na istočnojadranskoj obali, 162. Pretpostavci da nije riječ o „stvarima koje se same pokreću“, tj. životinjama kao dijelu imetka, ide u prilog kontekst obiju oporuka. Naime, izraz blago rabi se samo u prvoj, dok se u trećoj uopće ne spominje, već se specificiraju pojedini dijelovi imovine, među kojima nema životinja. Štoviše, navedene su samo „pokretne“ i „nepokretne stvari“, odnosno nekretnine i dio pokretnina, a umjesto izraza blago, u trećoj se oporuci pojavljuje nekoliko puta izraz bašćina kao općenitije određenje imetka. Usp. Iv. Eterović - Ig. Eterović, „Devet oporuka iz lovranske kancelarije“, str. 61, 67, 69.

64 Moglo bi se argumentirati u prilog tvrdnji da je treća oporuka tek kodicil, odnosno izmjena prve oporuke, tj. da to nije nova oporuka, nego izmjena stare. No nesklonost tom tumačenju proizlazi iz dvije činjenice. Prvo, u formalnom se smislu navodi da je treća oporuka anulacija, odnosno poništenje prve oporuke, a samim time pisana je kao nova oporuka. Drugo, u sadržajnom smislu došlo je do značajne izmjene u raspodjeli legata te je teško govoriti o pukim izmjenama prve oporuke, već je ona suštinski izmijenjena. 
U drugoj oporuci oporučitelj ostavlja svojim ukućanima relativno izdašne legate, no i jasno određene obveze. Legate možemo držati prilično izdašnima s obzirom na to da je ipak riječ o nekretnini - skladištu, najvjerojatnije trgovačkom, i to smještenu u ikarskoj luci. Osim toga svaka je kći dobila po jedno stablo pitomoga, odnosno divljega kestena. O ostaloj baštini možemo nagađati, ali s obzirom na to da kancelaru ostavlja kuću u gradu (možda stara lovranska gradska jezgra) tek za naplatu nekoga duga, moguće je da je riječ o uspješnu, imućnijem trgovcu iz toga kraja koji je baratao većim iznosima novca i bavio se kupoprodajom nekretnina.

U oporuci 4 oporučiteljica Polona, kći Ivana Žiganta, zbog nebrige članova vlastite obitelji ostavlja sve sucu Jakovu Blagaru i njegovoj nevjesti, odnosno županu Baćiću, prema kojemu je imala obvezu od ranije.

Vrlo je zanimljiva raspodjela imovine u oporuci Frančeska Palmića (5). Najveći dio ostavljen je sinu pokojnoga Jurja Antića Ivanu, za kojega je moguće da je oženjen jednom od oporučiteljevih kćeri, možda Jelenom ili Matejom, s obzirom na to da one eksplicitno nisu dobile ništa, a imaju obvezu sa sestrom Margaretom dijeliti obvezu služenja misa za svoju majku. Druga je od tih dviju kćeri najvjerojatnije ranije već udana, a obveze prema njoj (miraz) podmirene.

Anton Fratar, u oporuci 6, ostavlja svoju ženu Jelenu za gospodaricu svega imanja do njezine smrti, nakon koje sve pripada njegovim kćerima, koje imaju podijeliti među sobom jednako čitavu baštinu (svakoj polovica baštine). On ih ujedno obvezuje da, budu li u mogućnosti, osiguraju 20 stajanih misa nakon njegove smrti.

Sedma je oporuka mnogo sadržajnija. Oporučitelj Frančesko Martinčić vrlo precizno dodjeljuje legate svakom pojedinom nasljedniku. Sirote, očito žena i kć(er)i prvoga sina, dobile su popriličan dio imovine te su s ostalim sinovima oporučitelja određene kao glavni nasljednici. Šimun je dobio također značajan dio imovine, no Jakov je dobio najviše. Da je Jakov dobio zasigurno nesrazmjerno veći dio od ostalih nasljednika, da naslutiti bojazan oporučitelja da bi se oni mogli buniti, protiv čega ih uvjetuje već spomenutom oštrom sankcijom gubitka cijeloga dijela imovine.

U oporuci 8 oporučitelj Matej Geržinić ne govori o nasljedstvu, već svu svoju pažnju usmjerava na hijerarhiju nasljeđivanja. Naime gospodaricama imanja proglašava svoju majku i ženu, a nakon majčine smrti gospodarica svega imanja postaje sama žena. Nakon ženine smrti glavni nasljednik postaje 
sin Matej, a umre li on ranije, glavnom nasljednicom postaje kći Marija. Ako pak sin i kći umru prije njihove majke, glavni nasljednik ostaje žena.

Oporuka 9 najposebnija je u proučenome korpusu. S promjenom kancelara, očito se i praksa pisanja oporuka modificirala prema njegovu načinu pisanja. Najprije, na temelju izjava svjedoka, kancelar ističe da njegov prethodnik nije htio sastaviti oporuku Lučije Udovičić zbog nezadovoljavajućih uvjeta u njezinu sastavljanju, konkretno nedovoljne starosti svjedoka. No daljnjim iščitavanjem doznajemo da je kancelar kao izvršitelje dopustio muža treće sestre Katarine Gergura Lazarića Vlašinara i njegova oca Martina, čime je dopustio mogućnost pristranosti. Najveće iznenađenje dolazi u završetku oporuke, gdje se spominje da je nakon Martinove napomene da nije ništa ostavila trećoj sestri oporučiteljica eksplicitno potvrdila da njoj ne ostavlja ništa jer kako se je oženila, rasdelen’jem je uzrokovala veliku škodu $i$ rasuće svega stana ${ }_{9: 41-42}$. Tako je sve imanje oporučiteljica raspodijelila drugim dvjema sestrama Antoniji i Mariji, stricu Mateju Sirotnjaku i nekome Mateu Lazariću.

Odabir nasljednika, popis nasljedstva i obveze dane nasljednicima predstavljaju silno bogatstvo za izučavanje različitih dimenzija lovranske svakodnevice s kraja 18. stoljeća. Možemo se složiti s drugim proučavateljima oporuka da su i u ovome slučaju podaci o oporučnim odredbama „najrječitiji svjedoci koji oslikavaju [...] društvenu stvarnost u svim područjima života i djelovanja. Oni su mjerilo materijalne moći, razine duhovnih dosega, stanja vjerskog života, estetskih zahtjeva, a ponajviše, u cijelosti gledano, mjerilo su kulture življenja.“55 Svaki od tih segmenata daje oporukama kao izvoru posebnu vrijednost i značenje.

\section{Značenje lovranskih oporuka}

Oporuke su općenito kao povijesna vrela u posljednje vrijeme i u našoj akademskoj zajednici počele dobivati zasluženu pažnju te se valoriziraju kroz različita čitanja: od povijesnih i pravnih preko filoloških i književnih do etnoloških i antropoloških. Pritom su te različite perspektive istaknule njihovu jedinstvenu vrijednost za osvjetljavanje povijesti svakodnevice i

65 Sivrić, Oporuke Kancelarïe stonskog kneza, 106. 
razine materijalne kulture (odjeća, obuća, alati, pokućstvo itd.) ${ }^{66}$, povijesti gospodarstva, pravne povijesti, povijesti religioznosti, običaja, tradicije i mentaliteta, pravnih praksi itd. ${ }^{67}$

Što se sadržaja oporuka tiče, u prvi plan treba staviti njihovu vrijednost za istraživanje pravne povijesti ovoga kraja, prije svega Lovrana. Međutim osobitu vrijednost imaju za istraživanje povijesti svakodnevice i kao takve vjerojatno su najzanimljivi izvori. Među privatnim ispravama zauzimaju „posebno mjesto s obzirom na vrijednost za povijesno istraživanje [...]. One predstavljaju vrijedan izvor podataka za proučavanje različitih vidova života [...] duboko zadirući u svagdanji život." ${ }^{68}$ Oporuke tako mogu biti vrijedan izvor za proučavanje gospodarskih prilika, religioznoga života, društvenih i obiteljskih odnosa, a već je na ovome, relativno malenu korpusu to sve već posve zamjetno.

\section{1. Pravno-administrativna povijest Lovrana}

Ni jedan spomenik pravnoga karaktera ili s elementima pravne isprave $s$ područja Lovrana i Lovranštine, izuzev nekoliko glagoljskih oporuka i Kvaderne kapitula lovranskoga, dosad nije doživio znanstvenu valorizaciju, a čak su i ti spomenici to doživjeli u mjeri u kojoj je to bilo u moći njihovu priređivaču i komentatoru, pokojnome Damiru Viškaniću. ${ }^{69}$ Sve su te isprave nastale do polovice 17 . stoljeća, ${ }^{70}$ pa su lovranske oporuke tim važnije za popunjavanje praznina u poznavanju pravnih odnosa na području Lovrana u kasnijem razdoblju. U tom su smislu osobito vrijedne sadržajne činjenice koje se tiču samoga nasljeđivanja. Štoviše, budući da nije sačuvan statut lovranske komune, a poznato je da su se statutima regulirale sve odred-

66 V. primjerice Zoran Ladić, „Legati kasnosrednjovjekovnih dalmatinskih oporučitelja kao izvor za proučavanje nekih oblika svakodnevnog života i materijalne kulture“, Zbornik Odsjeka za povijesne znanosti Zavoda za povijesne $i$ društvene znanosti Hrvatske akademije znanosti $i$ umjetnosti, 21, 2003., 1-28 i Ivna Anzulović, „Nakit na zadarskom području u povijesnim izvorima od 13. do konca 16. stoljeća“, Radovi Zavoda za povijesne znanosti HAZU u Zadru, 48, 2006., 199-214.

67 Vrijednost oporuka za istraživanje različitih dimenzija prošle stvarnosti ističu brojni autori, primjerice Ladić, Last Will, 17, 23. Stoga su, zbog pomanjkanja drugih izvora, oporuke posebno prepoznate kao vrijedan izvor za istraživanje srednjovjekovnoga i ranonovovjekovnoga razdoblja. Uz mnoge bibliografske jedinice citirane u ovome radu, za popis nekih od ostalih radova posvećenih oporukama v. Gordan Ravančić, „Oporuke, oporučitelji i primatelji oporučnih legata u Dubrovniku s kraja trinaestoga i u prvoj polovici četrnaestoga stoljeća“, Povijesni prilozi, 40, 2011., bilj. 2, 28, 34 i 38 . Kratak pregled autora u hrvatskoj historiografiji koji su svoju pažnju posvetili oporukama, s osnovnim referencama, v. također u Ladić, Last Will, 30-33.

68 Karbić - Ladić, „Oporuke stanovnika grada Trogira“, 161.

69 Damir Viškanić, „Dvije glagoljske isprave iz Lovrana (XVI. st.)“, Vjesnik Državnoga arhiva u Rijeci, 39, 1997., 3-29; isti, Quaderna capituli Lovranensis.

70 Usp. isti, Quaderna capituli Lovranensis, 20. 
nice notarske službe jedne komune ${ }^{71}$, analizirane nam oporuke daju vrijedne podatke o mnogim pravnim uzusima na njegovu području, posebice one koje se tiču broja i naravi sudionika sastavljanja isprava, u ovom slučaju oporuka, a to su autori isprava (oporučitelji), izvršitelji i svjedoci.

Žena je mogla biti oporučiteljem i slobodno raspolagati imovinom (usp. 4. i 9), a jednako tako biti i univerzalnom nasljednicom, bilo da je riječ o ženi oporučitelja (usp. 8) ili njegovoj kćeri (usp. 6). Žena je također zadržavala pravo biti gospodaricom imanja do nove udaje, odnosno dok bi ostala udovicom (usp. 1, 2, 3 i 6), a uz nju bi taj status mogla imati zajedno i majka oporučitelja do svoje smrti (usp. 8).

Taj naglasak da žena oporučitelja ostaje žena i gospodarica na imanju ima posebnu važnost. Naime takvo se imenovanje žene inače činilo izrazom donna et domina i bilo je tipično obilježje braka na istarski način, braka u kojemu je žena ravnopravna partnerica mužu, u kojemu ona ima posebnu sigurnost te ne može, primjerice, biti protjerana iz kuće (kao što je običaj u braku na mletački način). Usprkos raširenosti običaja ženidbe na istarski način od Trsta preko Krasa sve do Rijeke, često su muževi dodatno osigurali svoje žene naglašavajući da su one žene $i$ gospodarice, što je značilo da ona može trajno ostati u kući, ali uz uvjet da ostane udovica. ${ }^{72}$ U lovranskim je oporukama to vrlo konzistentno primjenjivano, gdje svi oporučitelji ${ }^{73} \mathrm{kva}$ lificiraju svoje supruge kao done $i$ madone (i cele gospodarice)..$^{74}$ To nam daje vrijednu potvrdu hipoteza prijašnjih istraživača koji su na temelju Lovranu susjednih komuna (Veprinac) mogli tek indirektno pretpostavljati da je slično bračno-imovinsko uređenje bilo prisutno na čitavoj istočnoj padini Učke. ${ }^{75}$

Sve rečeno o izvršiteljima govori u prilog činjenici da su izvršitelji prije svega morale biti osobe od oporučiteljeva povjerenja, ali su jednako tako mogle imati i komunalni ugled. Kao oni koji su, nakon smrti oporučitelja,

71 Nepobitan dokaz tvrdnje da u statutima istočnojadranskih komuna postoje jasne odredbe o obavljanju notarske službe ponudila je Grbavac, „Notarska služba i komunalno zakonodavstvo“, 53-75. Poseban naglasak na činjenicu da je raširenost pojave sastavljanja oporuke implicirala kao prirodnu pojavu statutarnu regulaciju pravila koja se tiču oporuka, posebno od kraja 13., odnosno početka 14. stoljeća pa nadalje v. u Ladić, Last Will, 36, 75 .

$72 \mathrm{O}$ braku na istarski način v. Margetić, Hrv. srednjovj. obiteljsko i nasljedno pravo, passim, a za spomenuto određenje žene kao žene i gospodarice v. u: isto, 96.

73 Izuzev jednoga oporučitelja (usp. 7), ne računajući onu u kojoj je supruga oporučitelja već umrla (usp. 5).

74. Usp. pustil je nadalje njega ženu za donu, i madonu, i celu gospodaricu do nje smerti ${ }_{1.25-96}$; puš́a njega dragu ženu Antoniju donu, i madonu, $i$ celu gospodaricu do nje smerti živući kako udovica ${ }_{2: 36-s ;}$; puš́a svoju ženu Polonu do nje smerti živući udovica donu, $i$ madonu, $i$ celu gospodaricu nada svem njigovem ${ }_{\text {.10-14 }}$; do smerti pušća za

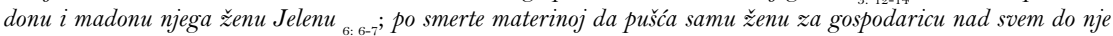
smerti ${ }_{8: 6-8}$

75 Margetić, Hrv. srednjovj. obiteljsko i nasljedno pravo, 143 
bili zaduženi popisati sva dobra, odnosno imetak pokojnoga oporučitelja u tzv. inventare dobara te raspodijeliti sva dobra prema oporučnim legatima pokojnika $^{76}$, izvršitelji su prije svega morale biti moralne osobe u koje je oporučitelj imao povjerenje. ${ }^{77}$

Za funkciju svjedoka zasigurno su bile tražene ugledne i pouzdane osobe, no morali su očito bili zadovoljeni i drugi uvjeti u vezi sa svjedocima, od kojih u korpusu imamo eksplicitno zasvjedočena dva: broj svjedoka (najmanji broj svjedoka jest dva) i određena starost (usp. 9). Broju i kakvoći svjedoka uobičajeno se velika pažnja posvećivala još od srednjega vijeka. Kakvoća svjedoka definirala se kroz nekoliko kategorija: dob, spol, pravni status, moralno-umnu prikladnost, dobar glas, imovno-radnu prikladnost i vjeru. Vidljivo je dakle, što se broja tiče, da i lovranski notarijat prati uobičajenu praksu uzimanja dvaju svjedoka pri sastavljanju oporuke, a može se zamijetiti i briga oko nužnih karakteristika adekvatnoga svjedoka: svjedoci su morali biti punoljetni (usp. 9), svi su bili muškarci. Budući pak da se u praksi podrazumijevalo da osoba udovoljava i ostalim kategorijama te ih se nije posebno navodilo ${ }^{78}$, to nam osim pravnih običaja govori nešto i o kvalitetama pojedinaca koji su sudjelovali kao svjedoci u sastavljanju analiziranih oporuka.

Oporuka je bila instrument koji je bio iznad propisa o obveznom nasljedivanju (tzv. legitima), ${ }^{79}$ ali da se zakonom određen „nužni dio“ poštovao i na tom prostoru dade se naslutiti iz samih oporuka ${ }^{80}$. Za neke konkretnije podatke o naravi legitime i nužnom dijelu na tom prostoru ipak treba čekati daljnja istraživanja na širem korpusu arhivskoga gradiva.

Osobito su vrijedne činjenice postojanja kancelarijskoga ureda koji je imao i funkciju notarijata u Lovranu, a vremenski posljednja analizirana oporuka otvara mogućnost istovremenoga postojanja čak dvojice notara u Lovranu u posljednjoj četvrtini 18. stoljeća - Antona Tomičića i Bartola Negovetića.

Posebno treba primijetiti da od ovih devet oporuka jedna predstavlja

76 Usp. Grbavac, „Notarska služba i komunalno zakonodavstvo“, 65.

77 Usp. Ladić, Last Will, 77.

78 Usp. Grbavac, Notarijat na istočnojadranskoj obali, 298-299.

79 „Oporuka kao pravni oblik u nasljednom pravu ima jaču snagu od zakona, što znači - primat odlukama oporuka, a potom zakon, ali uz uvjet poštovanja instituta nužnog dijela." Sivrić, Oporuke Kancelarije stonskog kneza, 48.

80 Usp. primjerice navod: er ako bi fundeval i decipeval, ordinuje da dat mu se nima stvari nijedne, van samu legitimu $_{\text {2: 22-24 }}$, što nam govori da sankcija u slučaju nepoštovanja oporučiteljeve volje koju on iskazuje ipak staje pred zakonskom obvezom „nužnoga dijela“. 
anulaciju (poništenje) jedne prethodno sastavljane (usp. $1 \mathrm{i}_{3: 6-11}$ ), a jedna potvrdu ranije isprave (dispozicije) od 30. rujna 1771. (usp. ${ }_{5: 6-8}$ ), što nam govori o mogućnosti da su kancelari ili drugi pouzdani pisari (kao što je u potonjoj oporuci lovranski crkveni dostojanstvenik) sastavljali središnji dio isprave, a zatim ga naknadno stavljali u formu oporuke sa svim potrebnim elementima. To su važne karike u daljnjem proučavanju pravne povijesti Lovrana i funkcioniranja notarijata na tom području.

\section{2. Položaj žene}

Oporuke su vrlo vrijedan izvor za istraživanje položaja žena kroz povijest te su u tom smjeru već objavljeni značajni radovi. ${ }^{81} \mathrm{Na}$ prvome mjestu treba istaknuti da je položaj žene u braku na istarski način bio mnogo povoljniji jer ju je stavljao u ravnopravan odnos s muškarcem; naravno, do one mjere u kojoj muž „ima više prava u upravljanju koliko mu pripada po izvjesnoj prednosti muškarca u obiteljskoj zajednici poslije smrti roditelja." ${ }^{2} \mathrm{U}$ svakom slučaju, položaj žena u pravnim uzusima Lovranaca koji daje naslutiti korpus ovdje analiziranih oporuka bio je već samom naravi uređenja bračno-imovinske zajednice „na istarski način“ daleko povoljniji od onih uređenih na mletački način.

Iako su u svim oporukama ovoga korpusa u kojima je oporučitelj imao muške potomke glavne nasljednike predstavljali upravo oni, čime je već žena stavljena u nepovoljan odnos prema muškarcu, a napose na pojedine sinove koji su dobivali najveći dio imanja (usp. 1 i 2), treba ipak uzeti u obzir povijesne okolnosti u kojima je muškarac obično bio uzdržavatelj obitelji te je žena bila obvezna najčešće tek donijeti miraz u muževu kuću, a koji je kao legitima bio zakonski dio koji je ona morala dobiti u nasljedstvo. Svi su muški oporučitelji u ovom korpusu, izuzev jednoga (8), ženu proglašavali gospodaricom svega imanja do njezine smrti ili nove udaje, čime se odavalo poštovanje prema udovici oporučitelja i osiguravala njezina egzistencija. Posebno je zanimljiv slučaj u kojemu oporučitelj striktno naglašava da je dio imovine žene pustil za divojaštvo (...) da ona ovo mozi pustit kamo njoj bude drago ${ }_{3: 53-55}$. Dakle žena je dobila dio imanja kojim može raspolagati po svojoj volji. U jednoj se oporuci posebno pak ističe da žena oporučitelja zaslužuje poniznost, posluh i poklonstvo $_{2: 39-40}$.

81 Usp. npr. Marija Mogorović Crljenko, „Položaj kćeri u istarskoj obitelji u 15. i 16. stoljeću“, Povijesni prilozi, 29, 2005., 59-77.

82 Margetić, Hrv. srednjovj. obiteljsko i nasljedno pravo, 96. 
Posebno su zanimljive odredbe u oporukama kojima se glavni nasljednici uvjetuju brigom za svoju sestru: ordinal je da [...] héere [...] donapunit njoj imaju svi eredi njegovi, ča još bi njoj mankalo ${ }_{3: 45-47}$. U jednoj je pak oporuci slično uvjetovanje vezano uz majku oporučitelja: ordinuje $i$ odlučuje da mater staru teštadurovu toliko njegova žena, koliko njega eredi nju imaju prinastat, prigljedat $i$ do smerti prihranit, kako je $i$ on živući učinil ${ }_{2: 32-35}$. Dakle vodilo se računa o osiguranju egzistencije i adekvatne brige za ženske potomke (vjerojatno najčešće do udaje) i majku oporučitelja (do smrti).

Sve to upućuje da je, usprkos činjenici da su sinovi preferirani kao glavni nasljednici te su dobivali veći dio imanja, ipak svojim nasljednicama oporučitelj nastojao osigurati egzistenciju ili barem dio imanja koji bi im eventualno mogao poslužiti kao pristojan miraz (dota) ili pak njegova nadopuna.

\section{3. Obiteljski odnosi}

Izvanredan primjer uzorna skrbljenja za roditelje predstavlja oporuka u kojoj najveći dio imovine s kućom, pokućstvom i sa svim što se u kući nalazi oporučitelj Frančesko Martinčić ostavlja sinu Jakovu koji se o njemu brinuo do njegove smrti ${ }_{7: 30-33}$. Kao dobar primjer poštovanja prema roditeljima dodatno treba uputiti na prije spomenuti odnos prema majci u kojemu oporučitelj ordinuje i odlučuje da mater staru teštadurovu toliko njegova žena, koliko njega eredi nju imaju prinastat, prigljedat $i$ do smerti prihranit, kako je i on živući učinil $_{\text {2: } 32-35}$.

Primjer neadekvatna odnosa prema članu obitelji nalazimo u oporuci u kojoj oporučiteljica Polona ostavlja sve sucu Jakovu Blagaru budući da nijedan od nje rodbine ni nju hotel prigljedat $i$ prinast niti $u$ zdravju niti u sadašnjo boleste $_{4: 5-7}$. Nepoštivanje roditeljske volje, kako je shvaća oporučiteljica, nalazimo u oporuci u kojoj oporučiteljica Lučija Udovičić svojoj trećoj kćeri Katarini pustit [...] neće ništar, za uzrok da kako se je oženila, rasdelen'jem je uzrokovala veliku škodu i rasuće svega stana ${ }_{9: 40-42}{ }^{83}$

\section{4. Pobožnost}

Oporuka je od srednjega vijeka tijekom vremena postala neizostavnim dijelom pripreme za dobru smrt, kada je ona „prije svega sredstvo sređivanja

83 Ipak treba naglasiti da je zasigurno većina poštivala stroge tradicionalne moralne nazore proizišle iz tradicionalnih odnosa ili kršćanske etike te je ponašanje u obitelji, posebno odnos prema ženama, barem kako je to vidljivo iz samih oporuka, u velikoj mjeri ovisilo o pravnim odredbama koje su se poštivale na području Lovrana. Zapravo možemo reći da su rijetke pobune protiv tradicionalnih uzusa ponašanja samo dokaz vrlo striktna poštivanja zadanih pravnih načela i normi. 
računa sa svijetom i s Bogom. Umrijeti bez oporuke značilo je ne samo da će nasljednici imati neprilike, već prije svega to da pokojnik ili pokojnica nisu bili vrli kršćani i građani i da se nisu dobro pripravili za 'veliki prijelaz'. Nenadana smrt, bez oporuke, ispovijedi i svjedoka smatrala se sramotnom i nečasnom. " ${ }^{44}$ To sređivanje računa na oba plana i u lovranskim je oporukama posve zamjetno i međusobno isprepleteno. Naime „ovozemaljske“ račune oporučitelji sređuju raspodjelom imovine i posmrtnim vraćanjem dugova dužnicima, no osiguravanje života nakon svoje tjelesne smrti oni također pokušavaju ostvariti svojim legatima.

Dvije su vrste takvih legata: ad pias causas i pro anima. ${ }^{85}$ Prvi, kako im ime govori, legati su u milosrdne svrhe, odnosno odredbe ostavljanja imovine za ubožnice, siromašne i bolesne i njih u analiziranim lovranskim oporukama nema. Drugi pak legati imaju svrhu pripomoći u spasenju pokojnikove duše i njih u razmatranim oporukama imamo zasvjedočene u obliku obveze služenja misa za pokojnikovu dušu i obveze hodočašća na sveta mjesta.

Ti se legati mogu uzimati kao zasigurno najvjernije osvjedočenje individualne pobožnosti, koja u sebi sintetizira religioznost standardiziranu normama i masovnu religioznost, te su oporuke, uz osobne dnevnike, najbolja vrela za njihovo istraživanje. ${ }^{86}$ Iako su mise zadušnice glavni oblik legata pro anima koje nalazimo u oporukama ovoga razdoblja ${ }^{87}$, oni nesumnjivo predstavljaju iznimno i prvoklasno vrelo za istraživanje pobožnosti Lovrana, ali i šire, krajem 18. stoljeća jer „oporučne legate za spas duše pro anima promatramo kao iskaz pučke pobožnosti na osobit način jer ni u kojem drugom dokumentu ne nalazimo tako dojmljiv i neposredan dokaz iskrenih namjera individua, tzv. malih ljudi, kako je to slučaj s oporukama.“88 Drugi je oblik legata briga o pokopu sa svim božanskim službama. ${ }^{89}$

84 Zdenka Janeković-Römer, „Na razmeđi ovog i onog svijeta: Prožimanje pojavnog i transcendentnog u dubrovačkim oporukama kasnoga srednjeg vijeka“, Otium, II, 3-4, 1994., 3.

85 Pregled historiografskih interesa za ovim legatima u europskoj historiografiji, no uz usporedbu s oporukama dalmatinskih komuna v. u: Zoran Ladić, „Oporučni legati pro anima i ad pias causas u europskoj historiografiji. Usporedba s oporukama dalmatinskih komuna“, Zbornik Odsjeka za povijesne znanosti Zavoda za povijesne $i$ društvene znanosti Hrvatske akademije znanosti $i$ umjetnosti, 17, 1999., 17-29.

86 Usp. Elvis Orbanić, Pučka pobožnost i neki aspekti društva Istre od kraja 15. do kraja 16. stoljeća na primjeru oporuka (dalje: Pučka pobožnost), magistarski rad, neobjavljeno, Zagreb 2005., 11-12.

87 „Važnost misa je bila takva da su one funkcionirale kao oruđe ubrzavanja posljednjeg putovanja duše iz kuće živih u kuću mrtvih."Ladić, Last Will, 43.

88 Usp. Orbanić, Pučka pobožnost, 3.

89 „Pokop je, uz mise, smatran najvažnijim pitanjem u ubrzavanju prelaska duše s ovog svijeta na onaj.“ Ladić, Last Will, 43. 
Tako Jakov Malinar Fratar u svojoj izmjeni (3:15-16;19-20 $)$ prethodno sastavljene oporuke $\left({ }_{1: 11-12}\right)$ ne dira u broj misa zadušnica: 30 pjevanih $^{90}$ misa, već samo dijeli obvezu na oba sina. Tomaso Mikuličić najprije obvezuje nasljednike da ga se pokopa u grobu predaka kako je red i sa svim božanskim službama (2:10-12 $)$, a nakon toga da se osigura po 20 pjevanih misa za njega i njegovu ženu po njihovoj smrti $\left({ }_{2: 41-47}\right)$. Polona Žiganto preporučuje se sucu Jakovu Blagaru, koji se brinuo za nju do smrti, da se pobrine i za njezin pokop $\left({ }_{4: 9-10}\right)$. Frančesko Palmić obvezuje svoje nasljednike da svojoj majci, njegovoj ženi, osiguraju dvaput sve zajedno 30 svetih misa ${ }^{91}$ zadušnica $\left(_{5: 27-32}\right)$. Anton Fratar obvezuje svoje nasljednike da mu osiguraju 20 stajanih $^{92}$ svetih misa, ako to budu u mogućnosti $\left({ }_{6: 12-15}\right)$. Matej Geržinić daje svim svojim nasljednicima zajedničku obvezu da održe tri stajane svete mise za oca oporučiteljeve žene Ivana, tri stajane svete mise za oporučiteljeva oca $($ deda $)$ i 5 malih $^{93}$ svetih misa za samoga oporučitelja $\left({ }_{8: 17-19}\right)$. Posljednja je oporuka specifična: u njoj Lučija Udovičić najviše legata posvećuje spasu duše. Ona obvezuje nasljednike na šest(?) stajanih svetih misa za dušu oca Antona (9: 14-15 $)$, šest(?) stajanih svetih misa za dušu majke Jelene (9:17-18$)$, dostojanstven pokop kako nalaže status njihove obitelji $\left({ }_{9: 22-23}\right)$, poslanje triju djevojaka na hodočašće Blaženoj Djevici Mariji u Kraj (9:30-32 ${ }^{94}$ i sveukupno 11 stajanih svetih misa za dušu oporučiteljice $\left({ }_{9: 20-21,26,35-36}\right)$.

Osim netom spomenute, još se jedna obveza hodočašća spominje, a to je ona u kojoj Jakov Malinar Fratar ostavlja dio imovine da bi se namirili troškovi za pašac od sveteh vrat Anjelske $u$ Sizu $_{3: 21}$, odnosno za hodočašće, „prolazak“ kroz vrata crkve svete Marije od Anđela u Asizu. ${ }^{95}$ Ovo je dokaz da je postojala praksa hodočašćenja u to glasovito franjevačko stjecište i iz lovranskih krajeva, kao što je to bila praksa općenito na istočnojadranskoj

90 Misa se pri služenju, pored govorenja i recitiranja, mogla i pjevati (Šetka, Hrvatska kršćanska terminologija, 159-160). Pjevana je misa zasigurno bila više na cijeni jer je iziskivala više napora u služenju.

91 Budući da nije navedeno, vjerojatno se radi o standardnu obliku služenja mise zadušnice.

92 Stajana je misa bila ona za koje se u vrijeme bogoslužja čitavo vrijeme stajalo i bila je zasigurno na cijeni više od standardne mise zadušnice.

93 Mala ili tiha misa ona je koja se govori bez ikakve vanjske svečanosti. Šetka, Hrvatska kršćanska terminologija, 159.

94 Ovaj je podatak dodatna potvrda tvrdnje da je „Crkva Majke Božje u Kraju (...) imala značenje hodočasničke crkve. Nekada je bila, prema predaji, puna zavjetnih slika koje su joj darovali vjernici.“ Vesna Bauer Munić, Sakralna arhitektura istočnojadranskih komuna od XII. do XVIII. stoljeća: Prilog spomeničkoj topografiji, Zagreb 2005., 150. Ovdje se otvara pitanje je li broj djevojaka imao nekakvo dodatno značenje, odnosno je li možda postojao neki uzus hodočašćenja u spomenutu crkvu.

95 Usp. Iv. Eterović - Ig. Eterović, „Devet oporuka iz lovranske kancelarije“, 84, bilj. 25. Inače je Asiz bio jedno od tzv. najvećih hodočasničkih mjesta (peregrinationes maiores) u Europi. Usp. Ladić, Last Will, 50. 
obali $^{96}$, a vrijednost se oporuka ogleda i u tome što su one zapravo gotovo jedini izvor za lovransku povijest hodočašća. ${ }^{97}$

Sve ovo upućuje na veliku razinu pobožnosti Lovranaca druge polovice 18. stoljeća. Gotovo svi oporučitelji brinu za svoje spasenje ostavljanjem obveze održavanja misa zadušnica za sebe $(1,2,3,6,8$ i 9), a mnogi brinu i za organizaciju sahrane (2, 4 i 9). Većina brine i za spasenje svojih najmilijih (usp. 2, 8 i 9), od čega neki čak isključivo samo za svoje najbliže i ostavljaju takve legate (5). ${ }^{98}$ Treba imati na umu da je svaka vrsta mise zadušnice zacijelo nosila drugačiju težinu, ali i cijenu.

Već na ovom uzorku sasvim je jasno vidljivo da su u lovranskim oporukama zasvjedočeni jednaki obrasci ostavljanja legata za spas duše zastupljeni i u drugim komunama na istočnojadranskoj obali još od srednjega vijeka. Možemo stoga zaključiti da lovranske oporuke pokazuju kako se tijekom nekoliko stoljeća religioznost u Lovranu praktički petrificirala, tj. da ne dolazi do promjena u odnosu na srednji vijek - osnovni pobožni motivi oporuka jednaki su.

\section{Zaključak}

U oporukama se krije pravo bogatstvo i za povjesničare i za filologe. One su jedinstven prozor u svakodnevicu i život maloga čovjeka u određenome prostornome i vremenskome odsječku. Već i ovako malen korpus kakav je analiziran u ovome radu nudi uvid u pravne običaje, obiteljske odnose, položaj žene, pobožnost i ekonomski status ljudi s Lovranštine u drugoj polovici 18. stoljeća. Jezična analiza odabranih devet oporuka pruža temelj za povijesnojezično istraživanje govorene i pisane riječi Lovranštine, ali i širega područja toga doba, pružajući istovremeno i važan okvir za iščitavanje onomastičke građe. $\mathrm{Na}$ jednome mjestu nalazimo istovremeno austrijski pravno-administracijski aparat, mletačke uzuse u svakodnevnom ophođenju (stil sastavljanja pravnih akata, uporaba novca...) te uporabu hrvatskoga jezika (čakavskoga narječja). Upravo se interdisciplinarnim pristupom, kakav je primijenjen i u ovome radu, zahvaća djelić složenoga suživota koji

96 Usp. Lovorka Čoralić, ,,Odredište Asiz: hodočašća u oporukama hrvatskih iseljenika u Mlecima“, Historijski zbornik, 42, 2009., 72-73. Za popis referenci koje se tiču hodočašća s istočnojadranske obale u svetišta na Apeninskom poluotoku v. isto, 72, bilj. 3. Treba istaknuti da je ova povjesničarka jedna od rijetkih koji se kontinuirano bave istraživanjem oporuka iz Državnoga arhiva u Veneciji, a koje se odnose na iseljenike s istočnojadranske obale pa tako djelomično i na Istru u novom vijeku. Usp. Ladić, Last Will, 30-31.

97 Usp. Ladić, Last Will, 51.

98 Samo u oporuci 7 nije zabilježen ni jedan legat za spas duše. 
je bio zastupljen na ovome prostoru i brojnih silnica unutar kojih se oblikovao njegov etos i etnos.

\section{Sažetak}

U fondu Javni bilježnici Rijeke i okolice pohranjenu u Državnome arhivu u Rijeci čuva se i vrijedna zbirka lovranskih oporuka iz 18. stoljeća, od kojih je najveći broj pisan talijanskim jezikom, a u potpunosti hrvatskim jezikom pisano ih je samo devet. Osam ih potpisuje notar Anton Tomičić, a najmlađu Bartol Negovetić. Faksimil, prijepis i transkripcija tih oporuka već su objavljeni, no zbog ograničena su prostora bile opisane samo njihove vanjske karakteristike, pa se u ovome radu koncentriramo na analizu njihovih unutarnjih karakteristika: strukturu, sadržaj i jezik. Pritom je naš osnovni cilj iskoristiti bogatu građu s povijesnoga i filološkoga aspekta.

Na početku rada dan je povijesni kontekst nastanka oporuka te kratak pregled njihove specifičnosti kao povijesnih izvora. Činjenica da je u Lovranu mjesto javne vjere u 18. stoljeću uz lokalni kaptol bila i notarska kancelarija govori u prilog tezi da je Lovran u to vrijeme predstavljao snažno administrativno središte.

U radu se potom predstavlja grafija obojice notara te temeljne jezične značajke. Obojica notara pišu hrvatskom nenormiranom dopreporodnom latinicom po talijanskome uzoru, no Tomičićevo je bilježenje dosljednije i ujednačenije, dok su u Negovetićevoj oporuci brojniji dvoznačni grafemi i višestruka rješenja, što upućuje na mnogo veće Tomičićevo notarsko iskustvo. Utvrđene fonološke i morfološke značajke pokazuju da je u osnovi jezika oporuka čakavski ekavski dijalekt.

Postupno se analizira struktura oporuka prema njihovim temeljnim dijelovima (protokol, korpus, eshatokol) te se zaključuje o uzusu njihova sastavljanja u lovranskom notarijatu, navode se neke specifične formule koje se u njima pojavljuju te daju prilozi za upotpunjenje slike o nekim običajima iz lovranske pravnopovijesne prakse. $U$ analizi sadržaja posebna se pozornost usmjerava na vrstu oporuka, način nasljeđivanja, osobe prisutne pri njihovu sastavljanju te zasvjedočene ostavinske odredbe.

Krajnji su zaključci doneseni u obliku razmatranja značenja ovih izvora za razumijevanje lovranske svakodnevice $s$ kraja 18. stoljeća. Osim pravno-administrativnih uzusa, posebno su izdvojeni položaj žene, obiteljski odnosi i pobožnost. Time se dokazuje upravo neophodna potreba korištenja ovih dragocjenih povijesnih izvora za sastavljanje mozaika mikropovijesti Lovrana i Lovranštine.

\section{Nove testamenti da Laurana dalla seconda metà del $18^{\circ}$ secolo: analisi storica e linguistica}

\section{Riassunto}

Nel fondo „Notai pubblici di Fiume ed i suoi dintorni” (Javni bilježnici Rijeke i okolice), che si conserva nell'Archivio di Stato di Fiume, si trova una collezione preziosa dei testamenti lauranesi del $18^{\circ}$ secolo, dei quali il maggior numero è scritto in 
italiano. Completamente in lingua croata sono scritti nove testamenti, di cui otto sono firmati dal notaio Anton Tomičić e uno da Bartol Negovetić. La facsimile e le trascrizioni sono già pubblicati, ma solo con la descrizione delle loro caratteristiche esterne. Per questa ragione qui ci concentriamo sull'analisi delle loro caratteristiche interne: la struttura, il contenuto e la lingua. Il nostro obiettivo principale è quello di analizzare il ricco materiale considerandolo dall'aspetto storico e filologico.

All'inizio si descrive il contesto storico in cui sono stati creati i testamenti e si da una breve panoramica della loro specificità come fonti storiche. Il fatto che in Laurana nel $18^{\circ}$ secolo il posto della fede pubblica, tranne il capitolo locale, fu anche la cancelleria notarile suggerisce che Laurana in quel tempo era un forte centro amministrativo.

Nell'articolo si presenta poi la scrittura latina dei testamenti e le caratteristiche più importanti della loro lingua. Entrambi i notai usano la scrittura latina croata prerisorgimentale non codificata di modello italiano, ma quella di Tomičić è più coerente ed uniforme, mentre nella versione di Negovetić troviamo più grafemi ambigui e soluzioni moltepliche. Questo indica che Tomičić ha un esperienza più grande come notaio. Le caratteristiche della lingua sul livello fonologico e morfologico dimostrano che la sua base è il dialetto ciacavo ecavo.

Dopo l'analisi linguistica si presentano gli elementi principali della struttura dei testamenti e si conclude sui modi della loro stesura nella cancelleria lauranese. Oltre questo si individuano alcune formule specifiche le quali si usano nei nove testamenti e si contribuisce alla conoscenza approfondita di alcuni costumi storico-legislativi a Laurana. Nell'analisi del contenuto un'attenzione particolare si dedica al tipo del testamento, modi ereditari, persone presenti alla loro compilazione ed attestate disposizioni testamentarie.

Le conclusioni finali riguardano il significato di queste fonti storiche per la comprensione della vita quotidiana di Laurana alla fine del $18^{\circ}$ secolo. Oltre ai costumi legislativi, si esamina lo stato della donna, le relazioni familiari e la religiosità. Questo dimostra la necessità indispensabile dell'uso di queste preziose fonti storiche per assemblare un mosaico della microstoria di Laurana ed i suoi dintorni.

\section{Ten last wills from the $2^{\text {nd }}$ half of the $18^{\text {th }}$ century Lovran: historical and linguistic analysis}

\section{Summary}

The National archives in Rijeka stores a valuable collection of $18^{\text {th }}$ century last wills in its Public notaries of Rijeka and surrounding area archival records. Most of them are written in Italian language, only nine of them are written solely in Croatian language. Eight of the before mentioned documents are signed by notary Anton Tomičić, while the latest is signed by Bartol Negovetić. Copies and transcripts of those wills have already been published, however, due to limited space, only their outer characteristics have been described, thus, this article is focusing on the analysis of their inner characteristics: structure, content and language. Our main goal is to use the rich archival records from the historical and philological stand. 
A historical context of the wills' formation has been covered, as well as a short overview of their specific characteristics as historical source. The fact that Lovran in the $18^{\text {th }}$ century had a notary office alongside public trust of the local Archdiocese supports the thesis that Lovran was a powerful administrative centre at the time.

Article then continues with description of both notaries' handwriting and basic linguistic features. Both notaries write in Croatian unofficial pre-revival Latinbased language modelled on Italian language, however, Tomičić's writings are more consistent and uniform, while Negovetić's will contains more ambiguous graphemes and multiple solutions, which implies that Tomičić had a larger notary experience. Determined phonological and morphological features reveal that linguistically the wills belong to Chakavian Ekavian dialect.

The structure of the wills is gradually analyzed by their basic parts (protocol, corpus, signature and date). They are concluded by mentioning the cause of their composition in the notary office in Lovran, certain characteristically formulated phrases appear and some customs from Lovran's legal history are mentioned, which completes the picture. During the analysis of content, special attention is given to that category of wills, the mode of inheritance, persons present at the composition and testifying the probation of the will.

The ultimate conclusions are presented as musings over the meaning of these records for the understanding of Lovran's everyday life at the end of $18^{\text {th }}$ century. Alongside legally-administrative customs, special attention is given to the position of women, hierarchy within families and religiousness. All of this proves that it is necessary to use these precious archives when completing the mosaic of the microhistory of Lovran and its surrounding area. 
